\title{
On the type materials of the genera Interatherium Ameghino, 1887 and Icochilus Ameghino, 1889 (Interatheriidae, Notoungulata, Mammalia) from early Miocene of the Santa Cruz Province, Argentina
}

\author{
MERCEDES FERNÁNDEZ ${ }^{1,2,3,5}$, JUAN CARLOS FERNICOLA ${ }^{1,2,3}$ \& ESPERANZA CERDEÑO ${ }^{3,4}$ \\ ${ }^{1}$ Departamento de Ciencias Básicas, Universidad Nacional de Luján, Ruta 5 y Avenida Constitución (6700), Luján, Buenos Aires, \\ Argentina.E-mail: mechi_985@hotmail.com; jctano@yahoo.com \\ ${ }^{2}$ División Paleontología de Vertebrados, Museo Argentino de Ciencias Naturales "Bernardino Rivadavia”, Av. Ángel Gallardo 470, \\ C1405DJR, Ciudad Autónoma de Buenos Aires, Argentina.E-mail:mfernandez@macn.gov.ar; jctano@macn.gov.ar \\ ${ }^{3}$ CONICET. Consejo Nacional de Investigaciones Científicas y Técnicas. \\ ${ }^{4}$ Paleontología, Instituto de Nivología, Glaciología y Ciencias Ambientales, Centro Científico Tecnológico-CONICET-Mendoza, Av. \\ Ruiz Leal s/n, 5500, Mendoza, Argentina.E-mail: espe@mendoza-conicet.gob.ar \\ ${ }^{5}$ Corresponding author.
}

\begin{abstract}
The first known Interatheriinae (Interatheriidae, Notoungulata) were described by Florentino Ameghino based on fossils collected by his brother Carlos in diverse Argentinean early Miocene outcrops in the Santa Cruz Province, which are housed at different institutions. In order to perform a systematic study of the subfamily, it is essential to revise as much specimens as possible, but first of all the type material of the species under study. Due to the fact that Florentino Ameghino never referred to any type specimens with a collection number in any of his publications, their identification becomes a complex task. In consequence, when studying the species erected by Ameghino within the genera Interatherium and Icochilus, we identified a lack of correspondence between some materials catalogued as type specimens and the original descriptions. In this contribution, we present the type specimens of 18 out of the 21 Santacrucian species of Interatherium (4) and Icochilus (14) within the paleontological collection of the Museo de La Plata and Ameghino National Collection at the Museo Argentino de Ciencias Naturales "Bernardino Rivadavia". Four case studies are presented: a) specimens correctly identified; b) materials erroneously catalogued as type specimens; c) specimens catalogued as type, whose status cannot be evaluated because they are lost; and d) specimens not catalogued as types, but herein recognised as such. As the selection of the type species of Icochilus was pending, Ic. extensus is herein designated as such. The lectotypes of Ic. extensus and Ic. multidentatus are selected among their identified syntypes.
\end{abstract}

Key words: Type specimens. Interatheriinae. Florentino Ameghino. Santa Cruz Formation. Pinturas Formation

\section{Resumen}

SOBRE LOS MATERIALES TIPO DE LOS GÉNEROS INTERATHERIUM AMEGHINO, 1887 E ICOCHILUS AMEGHINO, 1889 (INTERATHERIIDAE, NOTOUNGULATA, MAMMALIA) DEL MIOCENO TEMPRANO DE LA PROVINCIA DE SANTA CRUZ, ARGENTINA. Los primeros Interatheriinae (Interatheriidae, Notoungulata) en conocerse fueron eregidos por Florentino Ameghino a partir de fósiles colectados por su hermano Carlos en diversos afloramientos argentinos del Mioceno temprano en la provincia de Santa Cruz, los cuales están depositados en diferentes instituciones nacionales. Con el objetivo de realizar un estudio sistemático de la subfamilia, es esencial revisar la mayor cantidad de ejemplares posible, iniciando con los ejemplares tipo de las especies bajo estudio. Debido a que Florentino Ameghino nunca referenció formalmente los tipos con un número de colección, su identificación se torna una tarea compleja. En consecuencia, al estudiar las especies fundadas por Ameghino dentro de los géneros Interatherium e Icochilus, identificamos una falta de correspondencia entre ciertos ejemplares que aparecían catalogados como tipos y las descripciones originales. En esta contribución, presentamos los ejemplares tipo de 18 de las 21 especies santacrucenses de Interatherium (4) e Icochilus (14), alojados en la colección paleontológica del Museo de la Plata y la Colección Nacional Ameghino en el Museo Argentino de Ciencias Naturales "Bernardino Rivadavia". Se presentan cuatro casos de estudio: 
a) especímenes correctamente tipificados; b) ejemplares erróneamente tipificados; c) especímenes definidos como tipo en el catálogo, cuyo estado no puede ser evaluado porque están extraviados; y d) ejemplares no catalogados como tipos que aquí se reconocen como tales. Debido a que la selección de la especie tipo de Icochilus estaba pendiente, Ic. extensus se designa como tal. Los lectotipos de Ic. extensus e Ic. multidentatus son seleccionados a partir de los respectivos sintipos identificados.

Palabras clave: Especímenes tipo. Typotheria. Interatheriinae. Florentino Ameghino. Formación Santa Cruz. Formación Pinturas

\section{Introduction}

One of the first large collections of Tertiary fossil mammals was created by brothers Florentino and Carlos Ameghino, mostly based on fossils collected by Carlos during fifteen expeditions between 1887 and 1903 , in diverse fossiliferous outcrops of Patagonia (Argentina). Among them, fossils from the Santa Cruz Formation (Santa Cruz Province) in southern Patagonia, Santacrucian SALMA (early Miocene), particularly stand out. For more than a decade, Florentino used these specimens to describe and erect a remarkable number of mammal species, more than 200 within the order Notoungulata. Unfortunately, most of these species were rarely accompanied by illustrations and adequate diagnosis, and never published with catalogue numbers, facts that complicate the identification of the type materials. This becomes even more complex if we consider that Florentino and Carlos constructed an important private collection, which has been housed at the Museo Argentino de Ciencias Naturales "Bernardino Rivadavia" since the 1930s, in which F. Ameghino incorporated several specimens that undoubtedly belonged to the Museo de La Plata (Fernicola 2011a, b) and, at the same time, he sold many other specimens from it to foreign institutions (Vizcaíno 2011; Vizcaíno et al. 2013; Fernicola 2011b). Unfortunately, there is no confident and complete record regarding which specimens have been subtracted and even which ones have been sold and to whom. Consequently, many materials, including type specimens, are not located in their original reservoir and knowing their final location becomes rather difficult.

The confusion regarding both the final repository and the typification of some specimens has led to consider as missing some materials that are actually housed in another collection, as well as to have an incorrectly identification of a type material, which involves the lack of correspondence between the specimens used to erect the species and the specimens catalogued as types in the collections. Examples of these issues have been detected among marsupials by Marshall (1980), armadillos by Ciancio \& Carlini (2008), and the Interatheriinae Protypotherium and Patriarchus by Fernández et al. (2018); in the last case, the authors have proven the existence of erroneously typified Interatheriinae specimens. In this context and taking into consideration that type materials are the bearing specimens of a species name when it was first described (ICZN 2000: Art. 73), its wrong identification influences negatively any taxonomic revision, because it could lead to erroneous conclusions regarding the identity of the species and any further inferences on the taxon.

The present contribution deals with the cases of the Interatheriinae genera Interatherium and Icochilus. The interatheriines are a group of notoungulates that includes small $(0.5-10 \mathrm{~kg})$ rodent-like cursorial herbivores (Croft \& Anderson 2008; Townsend \& Croft 2008; Cassini et al. 2012; Elissamburu 2012) with hypsodont dentition. They are very well represented from the Tinguirirican (early Oligocene) to the Huayquerian SALMA (late Miocene; Cione et al. 2000) in the paleontological record of South America (Hitz et al. 2000). As part of an exhaustive taxonomic revision of the subfamily Interatheriinae (M. Fernández's Doctoral Thesis), we present herein a commented and illustrated catalogue of the type specimens of the species of Interatherium and Icochilus erected by Florentino Ameghino, housed at two Argentinean institutions, Museo de La Plata and Museo Argentino de Ciencias Naturales "Bernardino Rivadavia".

Historical background. In 1882, Francisco P. Moreno mentioned for the first time the taxa Interatherium, with Interatherium rodens, and Tembotherium, with T. holmbergii, based on specimens collected in 1876-1877 in Santa Cruz River (Moreno 1882: 117) from levels of the Santa Cruz Formation, Santacrucian SALMA. Nevertheless, due to the lack of descriptions, both genus and species names remained as nomina nuda (see ICZN 2000: Art.12). In 1886, while Moreno was the director of the MLP, Florentino Ameghino became subdirector of this institution and, as such, he sold his personal paleontological collection to the provincial state, keeping its guardianship in the MLP (Fernicola 2011b). A year later, Ameghino (1887a) formally described I. rodens and T. holmbergii as type species of the respective genera. 
Shortly after, over 2000 fossils recovered from the Santacrucian levels of the Santa Cruz River by his brother Carlos were deposited at the MLP (Ameghino 1887b; Fernicola 2011a, b). Almost all of these specimens were described by F. Ameghino (1887b), who founded Interatherium supernum, based on a mandibular fragment. In 1888, Ameghino was exonerated from MLP and, as mentioned by Fernicola (2011a, b), he deviated part of the Santacrucian specimens to his private collection, causing the fragmentation of the original collection into several reservoirs (e.g., Cruz et al. 2013; Vizcaíno et al. 2013) and the absence of some materials at the MLP.

In 1889, Ameghino synonymised I. rodens and T. holmbergii (1889: 195) and, as a result, Tembotherium became a synonymous junior of Interatherium. In addition, Florentino erected the genus Icochilus with four species (Ic. extensus, Ic. rotundatus, Ic. undulatus and Ic. excavatus), all of them based on specimens recovered in 1887 from the Santa Cruz Formation (Fernicola 2011a). Between 1889 and 1899, Carlos Ameghino went to different fossiliferous regions in Santa Cruz Province, and collected a significant amount of fossils that were later described by his brother (Ameghino 1891, 1894a, 1899), who erected other four Santacrucian species of Interatherium (I. brevifrons, I. anguliferum, I. interruptum and I. dentatum) and eleven of Icochilus, ten of which are related to the Santa Cruz Formation (Ic. robustus, Ic. senilis, Ic. lamellosus, Ic. trilineatus, Ic. anomalus, Ic. truncus, Ic. crassiramis, Ic. multidentatus, Ic. curtus and Ic. hegetotheroides) whereas Ic. ulter comes from the 'Astrapothericulan beds' (presumably the Pinturas Formation).

Abbreviations. Institutional abbreviations. AMNH, American Museum of Natural History, New York, USA; FMNH, Field Museum of Natural History, Chicago, USA; MACN, Museo Argentino de Ciencias Naturales "Bernardino Rivadavia", Buenos Aires, Argentina; MACN-A, Colección Nacional Ameghino at the MACN, Buenos Aires, Argentina; MLP, Museo de La Plata, La Plata, Argentina; YPM, Yale Peabody Museum of Natural History, New Haven, USA; ZMK, Zoological Museum of the University of Copenhagen, Copenhagen, Denmark.

Anatomical abbreviations. C/c, upper/lower canine; $\mathbf{d P / d p}$, upper/lower deciduous premolar; $\mathbf{I} / \mathbf{i}$, upper/lower incisor; $\mathbf{M} / \mathbf{m}$ upper/ lower molar; $\mathbf{m x}$, maxilla; $\mathbf{P} / \mathbf{p}$, upper/ lower permanent premolar; pmx, premaxilla.

Other abbreviations. ICZN, International Code of Zoological Nomenclature; L, length; MDL, mesio-distal length; SALMA, South American Land Mammal Age.

\section{Materials and methods}

We mainly limited our search to the specimens housed at two Argentinean institutions, MLP and MACN-A. These materials were studied by direct observation. Nevertheless, we also had at our disposal photographs of different specimens located in foreign institutions (e.g., AMNH, FMNH, YPM and ZMK); some of them belong to the authors and others have been kindly provided by colleagues.

Both Ameghino's personal collection and Ameghino's handwritten catalogue have been preserved at the MACN since the 1930's (Bordas 1936; Simpson 1984; Bond 2000; Fernicola 2011a). In his catalogue, Ameghino provided the inventory number of the specimen, the taxonomic assignment, a short description, and the year of collection, as well as indicated the specimens that belonged to the same individual. Ameghino sometimes labelled materials individually, whereas other times he used a single number for a lot constituted by multiple specimens. He numbered consecutively the fossils of his collection up to number 10316, but leaving uncatalogued materials, which were numbered from 10317 on after 1911-year of his death-. It is worth to mention that Fernández et al (2018) showed that, following Ameghino's written catalogue, the year of collection of an specimen is not entirely dependable; as a result, we decided not to rely on it in order to exclude a specimen as a type material, but to rely exclusively on the original descriptions and/or illustrations to identify the valid type specimens of Ameghino's species. On the other hand, we had at our disposal the catalogue of the "Old collections" of the paleontological Collection of the MLP.

In 1901, Ameghino allowed William Scott to visit his personal collection. During his visit, Scott took photographs of many of the specimens, which have been fortunately located (Vizcaíno et al. 2017). We have used this photographic catalogue trying to identify any of the materials currently considered to be lost. It is worth mentioning that, in contrast to what has been detected in other taxa such as sloths, Scott does not indicate any Interatheriinae type material in his catalogue. We have also consulted the extensive systematic catalogue made by Mones (1986), which summarised the information available on South American vertebrates in the multiple collection inventories, including the catalogue of the MACN-A, which contains the information of Ameghino's 
handwritten catalogue. Among other things, the author established the status of the type specimens of each species, although he remarked that, in the case of the MLP and MACN, the information was taken from the collection files, but he was not able to verify the accuracy of all the copied information and/or the real existence/location of the type materials (Mones 1886: 5). Consequently, any mistake in Ameghino's catalogue would have been duplicated by Mones.

With the aim of identifying the type material of the studied species, we have revised nearly 400 specimens, including skulls, mandibles and more or less complete fragments with teeth. These materials were confronted against the original descriptions and supplementary data such as measurements and illustrations published between 1887 and 1899 by F. Ameghino. Especially important are the illustrations published by Ameghino (1889: plate 15, 1891), which, in some cases, completed the description of the taxa published between 1887 and 1891. Unfortunately, the species founded between 1894 and 1899 were not illustrated and it was necessary to rely, exclusively, on their original diagnosis (Ameghino 1894a, 1899), which are usually very brief. Regarding the descriptions made by Ameghino in 1894, we follow the De Iuliis et al.'s (2016) proposal of recognizing the priority of the offprint version of that publication (Ameghino 1894a) instead of the printed version (Ameghino 1894b). Although both are identical works, they differ in their page numbering, which influences the posterior nomenclatural acts.

The original descriptions included in this contribution are transcribed in their original language-without updating grammatical rules - and are also translated into English. We do not make here any evaluation of any of the species, as this will be included in the definitive taxonomic revision of the group (MF's thesis).

The measurements indicated in this contribution were taken with a Kendo digital calliper $(0.02 \mathrm{~mm})$. The photographs were taken with Kodak Digital AZ651 and Nikon Micrometrics 318CU 3.2MP CMOS cameras. Concerning the selection of type specimens, type species and nomenclatural issues, this contribution follows the regulations established by the ICZN (2000). The dental nomenclature follows Smith \& Dodson (2003) and Hooker (1986), with some considerations taken from Reguero et al. (2003) for the upper dentition, and Vera and Cerdeño (2014) for the lower dentition.

\section{SYSTEMATIC PALAEONTOLOGY}

Notoungulata Roth, 1903

Typotheria Zittel, 1893

Interatheriidae Ameghino, 1887a

Interatheriinae Ameghino, 1887a

Interatherium Ameghino, 1887a

Interatherium Moreno, 1882: 117, nomen nudum. Ameghino, 1887a: 63, ex Moreno 1882.

Type species. Interatherium rodens Ameghino, 1887a: 63.

\section{Interatherium rodens Ameghino, 1887a}

Interatherium rodens Moreno, 1882: 117, nomen nudum. Ameghino, 1887a: 63, ex Moreno 1882.

Holotype. MLP 12-2826 (Fig. 1 A), right maxilla with alveolus of dP1, dP2 and P3-M3 series.

Age and provenance of the type material. Santacrucian SALMA, early Miocene, Santa Cruz Province (Argentina).

Original description (Ameghino 1887a: 63). "Talla comparable a la de una liebre. Paladar profundo, cóncavo, liso y con un pequeño agujero palatino en la sutura anterior del palatino con el maxilar. Sutura anterior del palatino con el maxilar al nivel del P4. Último molar superior implantado con su eje mayor en dirección de la serie dentaria. Apófisis cigomática del maxilar con un proceso descendiente suborbitario. Órbita del ojo, grande. 
Serie dentaria superior formando un arco muy pronunciado. [...] De este animal sólo se conoce el maxilar superior derecho con todas sus muelas, menos el pm. ', recogido por Moreno durante su viaje de 1876-1877'.

English translation. Size similar to that of a hare. The palate is deep, concave, smooth and presents a small palatine foramen anterior to the palatine-maxilla suture. This suture is at the level of P4. The last upper molar is implanted with its major axis in the same direction as the dental series. The zygomatic process of the maxilla presents a suborbital descending process. The orbits are large. Upper dental series forms a very pronounced arch. [...] This animal is only known by a right maxilla with all its cheek teeth, except for its P1, which has been collected by Moreno during his 1876-1877 exploration.

(A)

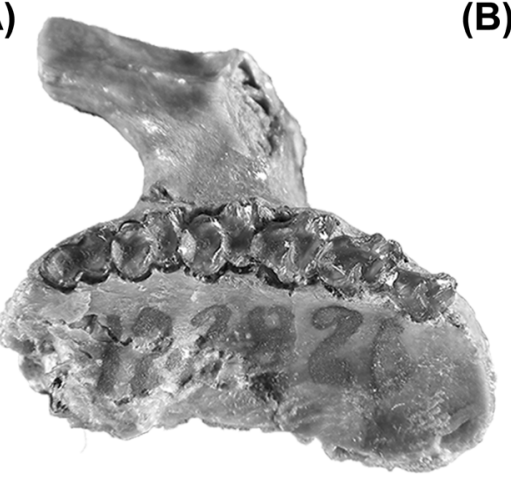

(B)

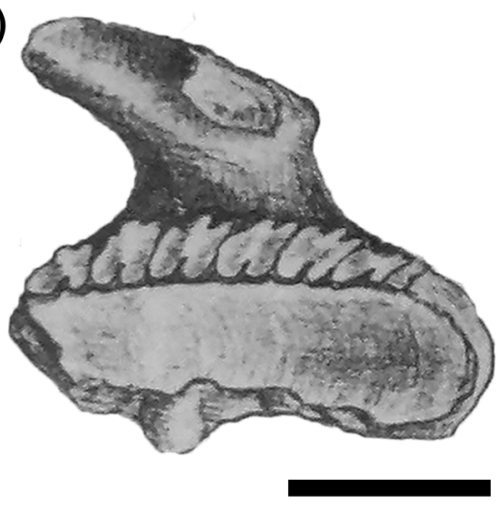

(C)

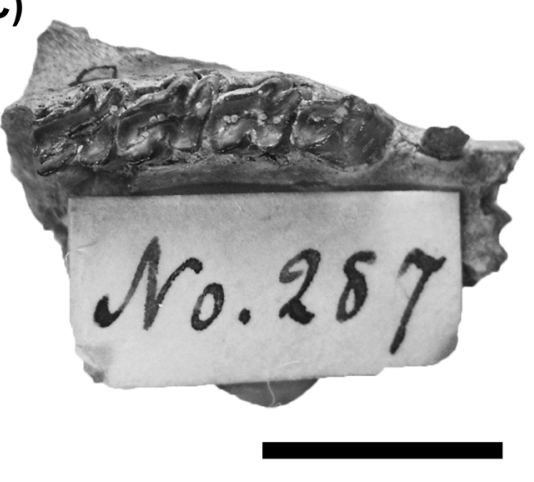

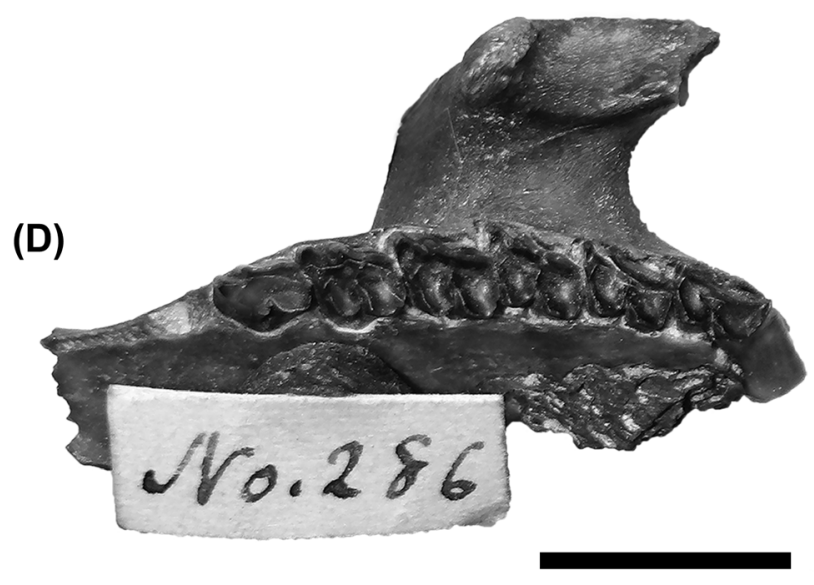

\section{(E)}

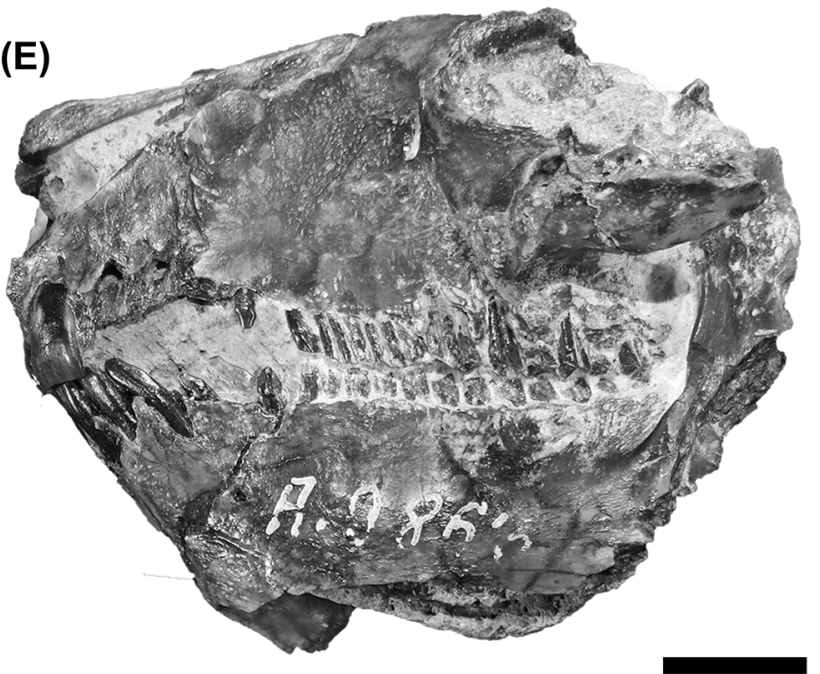

FIGURE 1. Interatherium rodens, holotype MLP 12-2826, right maxilla with alveolus of dP1 and complete $\mathrm{dP} 2$ and $\mathrm{P} 3-\mathrm{M} 3$, in occlusal view (A); reproduction of figure 26 (B) from Ameghino (1889, plate 15). Interatherium anguliferum, holotype MACN-A 3444, right maxilla with C and P2-M1, in occlusal view (C). Interatherium interruptum, holotype MACN-A 3445, left maxilla with the alveolus of $\mathrm{dP} 1$ and complete $\mathrm{dP} 2-3$ and $\mathrm{P} 4-\mathrm{M} 3$, in occlusal view (D). Interatherium dentatum, holotype MACN-A 9863, skull and mandible articulated, left lateral view (E). Scale bar $=10 \mathrm{~mm}$.

Comments. Ameghino (1887a) described this species based on a right maxilla collected by Francisco P. Moreno in 1876-1877. The same year, Ameghino (1887b) included other characteristics regarding I2-C and provided the length of dp1-p2-m3 series. Subsequently, Ameghino (1889: plate 15, figs. 20-26) significantly expanded his previous descriptions by studying some mandibular and cranial fragments that he also illustrated, including a maxilla herein reproduced (Fig. $1 \mathrm{~B}$ ). Florentino indicated that this specimen was in fact the maxilla used by Moreno to erect I. rodens and that it was deposited in the MLP at that time.

Despite Ameghino's acknowledgment regarding the status of the maxilla, he stated in his personal catalogue that MACN-A 377 to MACN-A 387 were the type materials of I. rodens. In contrast, Mones (1986) indicated the maxilla MLP 12-2826 as the type material of the species. This specimen is in fact the maxilla originally described 
and later illustrated by Ameghino (1887a, 1889) and, as a result, it is confirmed as the holotype of $I$. rodens. On the contrary, MACN-A 377 to MACN-A 387 are discarded as paratypes of I. rodens because, when reconstructing the history of these materials, they were given to Florentino by his brother Carlos in September of 1887, that is after the publication on the maxilla in April of 1887.

\section{Interatherium supernum Ameghino, 1887b}

Holotype. Not located, probably lost.

Age and provenance of the type material. Santacrucian SALMA, early Miocene, Santa Cruz Province (Argentina).

Original description (Ameghino 1887b: 15). "Tamaño mayor que el de la precedente [I. rodens]. Longitud de las siete muelas inferiores, $29 \mathrm{~mm}$. Muelas inferiores más anchas. $m 3$ con el lóbulo tercero apenas aparente".

English translation. Larger in size than the previous species [I. rodens]. Length of the seven lower cheek teeth, $29 \mathrm{~mm}$. Lower cheek teeth wider. $\mathrm{m} 3$ with the third lobe barely apparent.

Comments. Ameghino (1887b) founded and characterised this species based on a mandibular fragment with at least all of its cheek teeth, but he did not illustrate it. Later, Ameghino (1889, plate 15: figs. 17-19) notably expanded the original description based on fragmented mandibles and, mainly, a partial maxilla, all of them collected by C. Ameghino in Santa Cruz River in 1887 (Fernicola 2011).

In contrast to the original description, Ameghino's catalogue states that the maxilla MACN-A 424 is "tipo 1" ( $1^{\text {st }}$ type), an old and informal term used to refer to an holotype (C. Scioscia, pers. comm.), and that the partial mandibles MACN-A 357 (alveoli of right i1 and left i1-dp1 with complete p2-m1 series), MACN-A 358 (alveoli of left i1-dp1 and complete p2-3 series) and MACN-A 359 (broken left $\mathrm{p} 2$ and complete $\mathrm{p} 3-\mathrm{m} 2$ series) are "tipo 2", an informal and antique expression used to refer to a paratype (C. Scioscia, pers. comm.).

Within the Ameghino Collection, MACN-A 424, MACN-A 357 and MACN-A 540 (right fragmented mandible with dp2-m1) correspond to figures 17, 18 and 19, respectively, of Ameghino's Atlas (1889: plate 15). Nevertheless, none of these mandibular fragments is the holotype of the species, because they do not, either alone or combined, recreate the original dp1-p2-m3 series. Besides, as they do not present any evidence of recent break, it is inferred that they have not lost any dental piece through time in the collection. In addition, these materials do not present wide lower molariforms as originally described by Ameghino (1887b). Regarding the maxilla MACNA 424, it is also discarded as type material due to the fact that Ameghino (1887b) only described lower dentition of I. supernum. As a matter of fact, if he had had the maxilla at hand, he would have compared and contrasted $I$. supernum and I. rodens not only based on lower teeth but also on upper teeth, which he did in detail in 1889 , when he even recognised that the lower dentition of I supernum did not present anything in particular except its size and more continuous anterior dentition.

On the other hand, Mones (1986) indicated MLP 12-1846 (right mandibular fragment with p4-m3), MLP 121878 (incomplete left maxilla with P3-M2), MLP 12-1879 (right maxilla with broken P3, P4-M2, and broken M3), MLP 12-1885 (left mandibular fragment with p3-m1), MLP 12-1886 (right mandibular fragment with dp4-m2), MLP 1887 (right mandibular fragment with $\mathrm{p} 3-\mathrm{m} 1$ ) and MLP 12-1921 (left mandibular fragment with $\mathrm{p} 4-\mathrm{m} 2$ and broken $\mathrm{m} 3$ ) as the type specimens of I. supernum. In the collection of MLP, all these specimens are labelled as paratypes of I. supernum. However, MLP 12-1878 and MLP 12-1879 are discarded as type materials because they are maxillae. The same conclusion is inferred for the fragmented mandibles, because they do not exhibit the tooth row mentioned in the original diagnosis (Ameghino 1887b) and there is no evidence of any recent break. In the case of MLP 12-1846, which is the only specimen with complete m3, it does not exhibit the characteristics originally mentioned by Ameghino (1887b). It is worth mentioning that when comparing the labels of these specimens (indicating them as paratypes) with the Old Collections catalogue, which was written 30 years before the labelling (M. Reguero, pers. comm.), we noticed that there are many inconsistencies that make us question the veracity of the labelled information. On the one hand, none of the materials labelled as "paratype" is indicated as such in the Old Collections catalogue; in fact, the term is a modern expression that was never used by Florentino Ameghino. On the other hand, in contrast to the labels, there is no information in Old Collections catalogue concerning the collector and/or provenance of these specimens. Due to all of these facts and that there is no original tag that validates their status as paratypes or even confirms that any of these materials was actually collected by 
Carlos Ameghino in 1887 and used by Florentino Ameghino to describe I. supernum, they are all rejected as the paratypes of the species.

In summary, the holotype of I. supernum has not been located either in MACN-A and MLP collections or in any other collection revised by mean of photographs (e.g., AMNH, FMNH and YPM).

\section{Interatherium brevifrons Ameghino, 1894a}

Holotype. Not located, probably lost.

Age and provenance of the type material. Santacrucian SALMA, early Miocene, Santa Cruz Province (Argentina).

Original description (Ameghino 1894a: 18). "Espèce de taille beaucoup plus petite que le I. rodens et avec toute la denture en série continue, sans diastèmes. La partie antérieure du crâne est très raccourcie. L'i. ${ }^{l}$ est très grande et les $i^{2}{ }^{2}$ et ${ }^{3}$ très petites. La canine est bien développée. Longueur de la partie antérieure de l'i. ${ }^{1}$ à la partie postérieure de la $\mathrm{m}^{3}, 27 \mathrm{~mm}$ ".

English translation. Species much smaller in size than I. rodens and with all the dentition in continuous series, without diastemata. The anterior part of the skull is very short. I1 is very large and I2-3 are very small. The canine is well developed. Length from the anterior part of I1 to the posterior part of $\mathrm{m} 3,27 \mathrm{~mm}$.

Comments. Ameghino (1894a) did not add any illustration to the original description of the species. According to Ameghino's catalogue, the cranial fragment MACN-A 3440 is the type specimen of I. brevifrons. Instead, Mones (1986) indicates the fragmented maxilla MACN-A 3441 as such.

MACN-A 3440 does not match the original description because it does not exhibit a complete dental series and it presents two diastemata, anterior and posterior to the upper canine. Therefore, it is discarded as the type specimen of the species. On the other hand, MACN-A 3441 can neither be considered the type material, because it is a very fragmented specimen with only three molariforms (Ameghino's catalogue indicates "tres muelas" [three cheek teeth], so there is no option of having lost any dental piece through time).

Unfortunately, no material that matches the original description (Ameghino 1894a) was located within the studied collections.

\section{Interatherium anguliferum Ameghino, 1894a}

Holotype. MACN-A 3444 (Fig. 1 C), a fragmented right maxilla with C and P2-M1 series.

Age and provenance of the type material. Santacrucian SALMA, early Miocene, Santa Cruz Province (Argentina).

Original description (Ameghino 1894a: 18). "De taille intermédiaire entre celle de 1 'I. rodens et celle de 1 'I. supernum dont elle se distingue par l'absence de la première prémolaire supérieure. La canine supérieure est bien développée et isolée par des diastèmesen avant et en arrière. Les $p^{2} \grave{a}^{4}$ ont les deux arêtes perpendiculaires de l'angle antérieur externe très fortes. Longueur du bord antérieur de la canine au bord postérieur de la première vraie molaire supérieure, $17 \mathrm{~mm}$ ".

English translation. Size intermediate between I. rodens and I. supernum, from which it is distinguished by the absence of the first upper premolar. The upper canine is well developed and anteriorly and posteriorly isolated by diastemata. P2-4 have the two perpendicular columns of the antero-external angle very strong. Length from the anterior region of the upper canine to the posterior border of the first true upper molar, $17 \mathrm{~mm}$.

Comments. Ameghino (1894a) did not illustrate any specimen of this species. According to Ameghino's catalogue and Mones (1986), the maxilla MACN-A 3444 is the type specimen of the species. This material matches the original description provided by Ameghino (1894a) because its dP1 is absent, there are diastemata anterior and posterior to $\mathrm{C}$, and the series $\mathrm{C}-\mathrm{M} 1$ is $17.3 \mathrm{~mm}$ long. Therefore, MACN-A 3444 is confirmed as the holotype of I. anguliferum. 


\section{Interatherium interruptum Ameghino, 1894a}

Holotype. MACN-A 3445 (Fig. 1 D), left maxilla with the alveolus of dP1, and series dP2-3 and P4-M3.

Age and provenance of the type material. Santacrucian SALMA, early Miocene, Santa Cruz Province (Argentina).

Original description (Ameghino 1894a: 18). "De la taille de 1 'I. supernum. Cette espèce se distingue facilement par la présence de la première prémolaire supérieure qui est placée contre la partie antérieure de la deuxième, et par la disparition complète de la canine. Il y a une longue barre qui sépare la première prémolaire de l'incisive externe; le bord de cette barre porte un sillon longitudinal profond qui suit la même direction de la série dentaire. Longueur des sept molaires supérieures, $25 \mathrm{~mm}$ ".

English translation. With the same size as I. supernum. This species is easily distinguished by the presence of the first upper premolar that is placed against the anterior part of the second, and by the complete absence of the upper canine. There is a long diastema that separates the first premolar from the external incisor; the margin of this diastema shows a deep longitudinal groove that has the same direction as the dental series. Length of the seven upper molars, $25 \mathrm{~mm}$.

Comments. Ameghino (1894a) did not illustrate this species. According to Ameghino's catalogue and Mones (1986), the left maxilla MACN-A 3445 is the type specimen of the species. This material lacks the canine and, instead, exhibits a long diastema placed anteriorly to the alveolus of $\mathrm{dP} 1(\mathrm{~L}=4.1 \mathrm{~mm})$. It also shows the groove described by Ameghino, and the length of dP1-M3 is $24.8 \mathrm{~mm}$. All of this coincides with Ameghino's (1894a) description and, consequently, MACN-A 3445 is confirmed as the holotype of I. interruptum.

\section{Interatherium dentatum Ameghino, 1894a}

Holotype. MACN-A 9863 (Fig. 1 E), anterior cranial fragment and an almost complete mandible in anatomical connection.

Age and provenance of the type material. Santacrucian SALMA, early Miocene, Santa Cruz Province (Argentina).

Original description (Ameghino 1894a: 18). "Par la taille se rapproche de 1 'I. supernum; il s'en distingue pour posséder une prémolaire de plus à la mâchoire supérieure, c'est-à-dire cinq au lieu de quatre. Les deux premières prémolaires sont coniques, la première ou antérieure étant séparée de la deuxième. La série dentaire supérieure complète occupe un espace de $41 \mathrm{~mm}$ ".

English translation. It is close to I. supernum by its size; it differs from it in having an additional premolar in the maxilla, which means five instead of four. The first two premolars are conical, the first (or anterior) being separated from the second. The complete upper dental series occupies a space of $41 \mathrm{~mm}$.

Comments. Ameghino (1894a) did not add any illustration to the original description. No specimen is indicated as the type material of I. dentatum in Ameghino's catalogue, and Mones (1986) wrote "MACN ?", which means doubts or lack of information regarding the type that could be housed at the MACN.

There are three specimens assigned to I. dentatum within the Ameghino Collection: the articulated skull and mandible MACN-A 9863, and two fragmented maxillae, MACN-A 9864 and MACN-A 9865, corresponding to two different individuals. These maxillae lack its anterior portion, so the region that should contain the extra premolar is not preserved in any of them; as the areas of breakage are not recent, both specimens are discarded as the type. Instead, MACN-A 9863 matches the original description (Ameghino 1894a) as it presents an extra alveolus between $\mathrm{C}$ and $\mathrm{dP} 1$, which is separated from the latter by a distinct diastema. The length of left I1-M3 series $(41.3 \mathrm{~mm})$ also matches the only measurement provided by Ameghino (1894a). Consequently, MACN-A 9863 is considered the holotype of I. dentatum.

\section{Icochilus Ameghino, 1889}

Type species (this contribution). Icochilus extensus Ameghino, 1889: 471-472. 
Comments. Ameghino (1889) did not designate the type species of genus Icochilus among the four species originally defined within this taxon. Neither Sinclair (1909), who was the first reviewer, nor Mones (1986) noticed this omission. As a result, this nomenclatural act was pending until now, because for genera described before 1930, the reviewer must select the type species among those included within the genus when it was described (ICZN 2000: Art. 69). In this case, Ameghino (1889) defined Ic. extensus, Ic. excavatus, Ic. undulatus and Ic. rotundatus along with the generic description. As there is no priority criterion regarding the pages, the priority is determined by the reviewer (ICZN 2000: Art. 69). Therefore, we choose Ic. extensus as the type species, because its type material involves an almost complete individual with reliable and recognizable dental and craneo-mandibular features. In addition, the original diagnosis of the genus was based on this species due to its completeness, and was used by Ameghino as a reference for describing the remaining three.

\section{Icochilus extensus Ameghino, 1889}

Lectotype (this contribution). MACN-A 1083 (Figs. 2 A-B) and MACN-A 1084 (Figs. 2 C-D), an almost complete skull and mandible with complete dentitions, both belonging to the same individual.

Paralectotypes (this contribution). Four isolated teeth, not located (see below).

Age and provenance of the type material. Santacrucian SALMA, early Miocene, Santa Cruz Province (Argentina).

Original description (Ameghino 1889: 471-472). "Esta es la especie de mayor tamaño, cuya talla era un poco superior á la del conejo. Los premolares ${ }^{2},{ }^{3} y^{4}$ se distinguen fácilmente de los de las demás especies, por presentar sobre la parte anterior de la cara externa dos aristas estrechas separadas por una ranura angosta y profunda; de estas dos aristas, la anterior que forma el ángulo ántero-externo de cada diente es mas pequeña y mas baja, y la posterior mas ancha y considerablemente mas elevada tomando la forma de una columna perpendicular saliente. La parte posterior externa detrás de la columna mencionada es mas baja y plana, uniéndose á la cara posterior formando un ángulo redondeado. Los verdaderos molares superiores tienen las dos aristas de la parte anterior de la cara externa mas estrechas y de tamaño mas igual, sin que la segunda tome la forma de columna perpendicular saliente. Detrás de esta segunda árista viene una depresión perpendicular colocada sobre la mitad del ancho de la cara externa de la muela, de fondo cóncavo pero poco profunda. Cada uno de los verdaderos molares superiores presenta sobre el borde externo de la corona dos cúspides ó cerros puntiagudos, formados por el prolongamiento de las ondulaciones convexas perpendiculares de la cara externa. En la mandíbula inferior, los dos lóbulos que forman cada muela, son de forma mas distinta entre sí que en las otras especies; el lóbulo anterior tiene el lado interno mucho mas estrecho y en forma de arista perpendicular angosta y saliente dirijida hacia atrás, y el lado externo mas ancho y redondeado, con su eje mayor dirijido oblicuamente de afuera hacia adentro y de adelante hacia atrás, presentando la cara posterior de un ancho considerable; el lóbulo posterior es también igualmente muy estrecho sobre el borde interno y mas grueso sobre el externo, pero presenta su parte anterior que se une al lóbulo que lo precede considerablemente mas angosta que la posterior. La mandibula inferior presenta tres agujeros mentonianos, el anterior mas grande, colocado debajo de la barra que separa el $p .$, del $c_{.}$en el punto en que la sinfisis se comprime transversalmente para tomar la forma de pico, el segundo mucho mas pequeño está colocado debajo del $p_{\cdot 2}$, y el tercero igualmente pequeño, se encuentra debajo de la parte anterior del $p_{\cdot}$. La cara externa de la rama horizontal debajo de los premolares es gruesa y convexa. La rama ascendente presenta el borde anterior con la base que sale del lado externo de la última muela levantándose hacia arriba formando una pequeña curva cóncava, pero su parte superior que constituía la apófisis coronoides se inclina hácia adelante".

English translation. This is the largest species, being a little larger in size than a rabbit. P2-4 are easily distinguishable from those of the other species, because they have two narrow edges separated from each other by a narrow and deep groove on the antero-external face; of these two edges, the anterior one, which forms the anteroexternal angle of each tooth, is smaller and lower, while the posterior is wider and considerably higher resembling a perpendicular projecting column. The postero-external region behind this column is lower and flat, joining the posterior face in a rounded angle. M1-3 also presents two antero-external edges but both are narrower and of equal size, and the posterior edge does not take the form of a perpendicular projecting column. Behind this second edge, there is a perpendicular depression, concave but shallow, placed about half the width of the external face of the 
molar. Each molar has two pointed cusps or hills on the external margin of the crown which are formed by the prolongation of the convex and perpendicular undulations of the external face. In the mandible, the two lobes that constitute each tooth, are more distinct from each other than in the other species; the inner side of the anterior lobe is much narrower than the external and similar to a narrow, perpendicular and protruding edge which directs backwards, whereas the external side is broader and rounded with its major axis obliquely directed, with the posterior face being considerable wide; the posterior lobe is also very narrow on the inner face and thicker on the

(A)

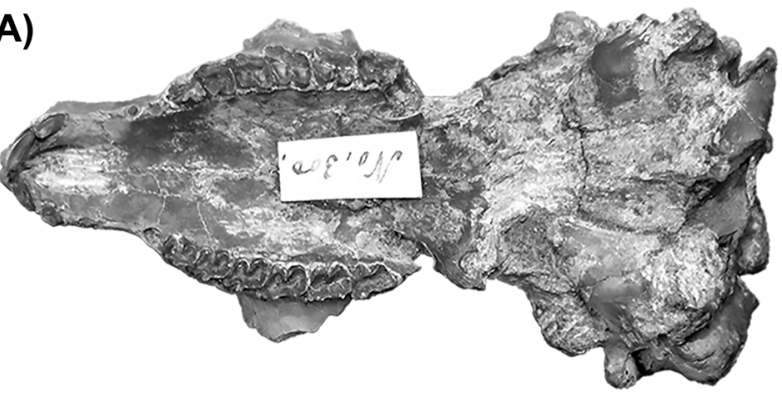

(B)

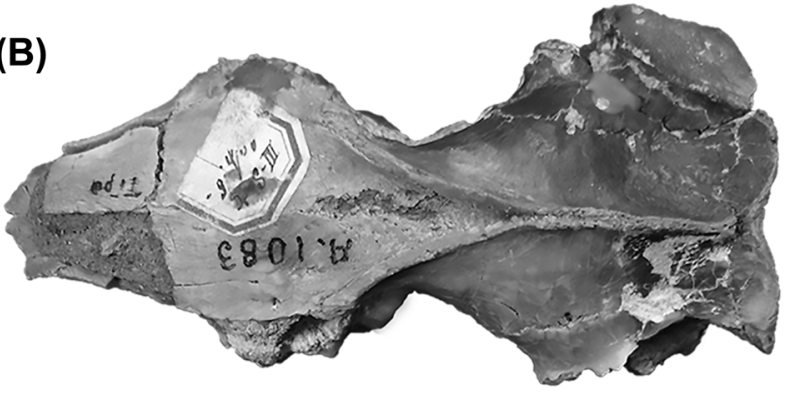

(C)

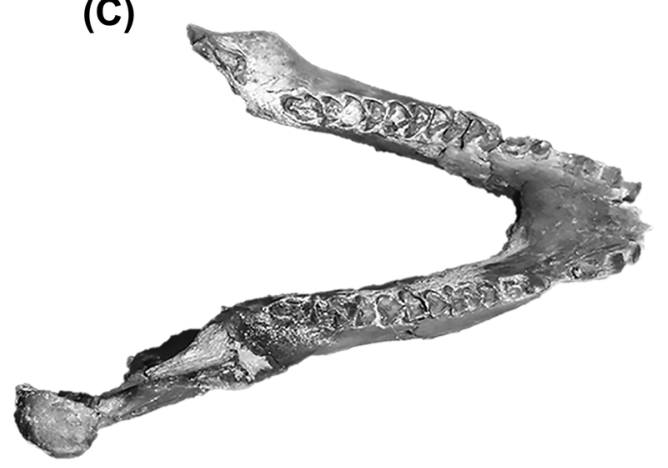

(D)

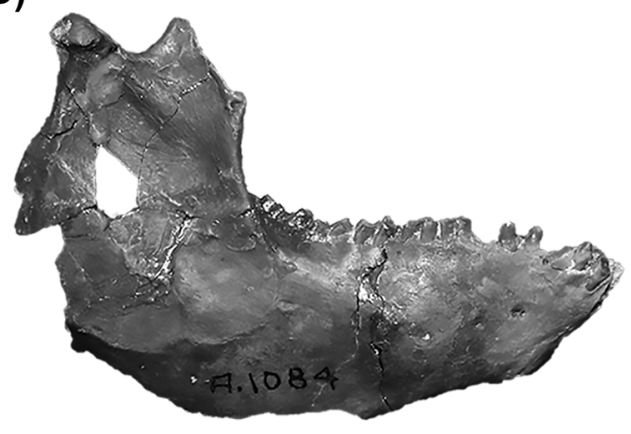

(E)
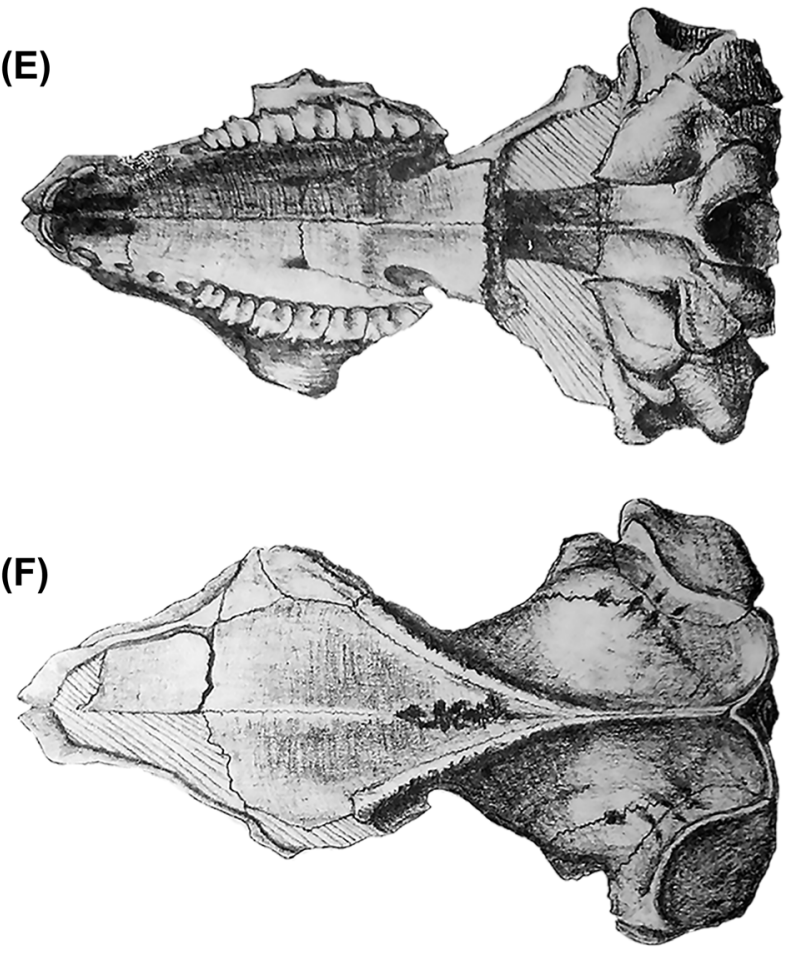

(G)

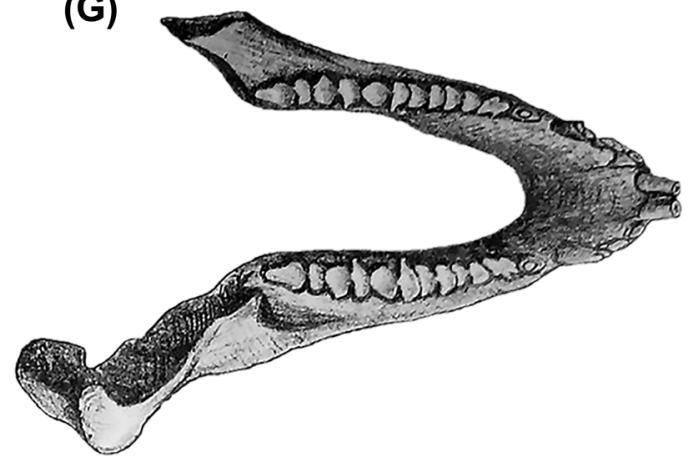

(H)

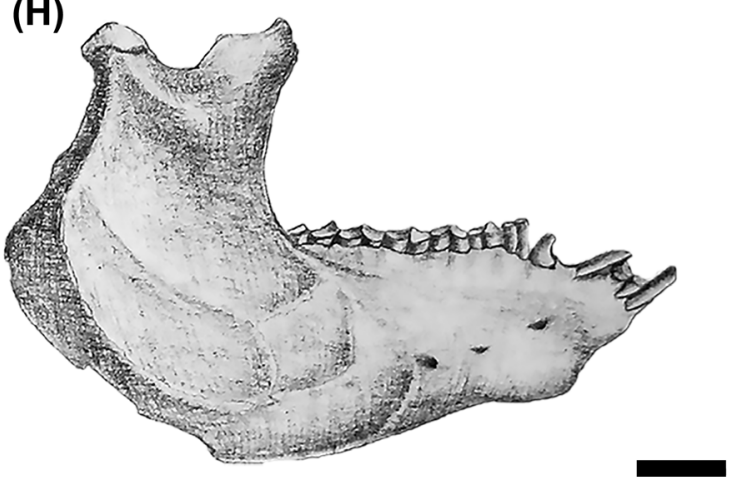

FIGURE 2. Icochilus extensus, holotype MACN-A 1083, incomplete skull in, ventral (A) and dorsal (B) views; holotype MACN-A 1084, incomplete mandible, in occlusal (C) and lateral (D) views; reproductions of the figures 4 (E), 4 a (F), 5 (G) and 5b (H) from Ameghino's Atlas (1889, plate 15). Scale bar $=10 \mathrm{~mm}$. 
external, but the anterior part that joins the preceding lobe is considerably narrower than the posterior lobe. The mandible has three mental foramina, the anterior is the largest and it is placed below the diastema that separates $\mathrm{p} 1$ from $\mathrm{c}$ at the point where the symphysis is transversely compressed acquiring the shape of a beak, the second is much smaller in size and it is placed below p2, and the third is equally smaller and is placed below the anterior margin of $\mathrm{p} 4$. Below the lower premolars, the external face of the horizontal mandibular ramus is thick and convex. The ascending ramus of the mandible presents its anterior border with the base that emerges from the external side of $\mathrm{m} 3$ rising upwards forming a small concave curve, but its upper part, which constitutes the coronoid process, slopes forwards.

Comments. Ameghino (1889: 471-472, plate 15: figs. 4-5) described and illustrated this species based on a partial skull and mandible of the same individual, along with four isolated teeth-I1, right upper premolar, right upper molar and left lower molariform-(Ameghino 1889, plate 15: figs. 6-9).

According to Ameghino's catalogue and Mones (1986), the skull MACN-A 1083 and the mandible MACN-A 1084 are the type specimens of Ic. extensus. Following Ameghino's catalogue, both are part of the same animal, which is confirmed by us because they articulate to each other. MACN-A 1083 and MACN-A 1084 correspond to figures 4 and 5, respectively, of the Atlas (Ameghino 1889: plate 15), and are herein reproduced (Figs. $2 \mathrm{E}-\mathrm{H}$ ). The isolated teeth (Ameghino 1889: plate 15, figs. 6-9), which were not even mentioned in the written catalogue, were not located in the collection and, due to the fact that MACN-A 1083 and MACN-A 1084 already exhibit these teeth, we conclude that they do not belong to the same individual as the skull and mandible; nevertheless, these teeth would be part of the original syntypes. As the original diagnosis was based on the characteristics of the skull and mandible, we designate MACN-A 1083 plus MACN-A 1084 as the lectotype of Ic. extensus. Consequently, the remaining syntypes become paralectotypes (ICZN 2000: Art. 73.2.2).

\section{Icochilus excavatus Ameghino, 1889}

Syntypes. MACN-A 9681 (Fig. 3 A), incomplete right maxilla with alveoli of C and dP1, and series P2-M3; MACN-A 177 (Figs. 3 B-C), mandibular symphysis with alveoli of both i1 and left series i2-p2; MACN-A 178 (Figs. 3 D-E), left mandibular fragment with c-m1; and MACN-A 179 (Fig. 3 F), right partial maxilla with two molariforms (probably M1-2). MACN-A 180 (maxillary or mandibular fragment according to the catalogue) and an unnumbered isolated $\mathrm{m} 3$ (originally illustrated) are currently missing.

Age and provenance of the type material. Santacrucian SALMA, early Miocene, Santa Cruz Province (Argentina).

Original description (Ameghino 1889: 472-473). "Esta especie era de un tercio mas pequeña que la precedente [Icochilus extensus], de la que se distingue por la conformación de la cara externa de los premolares y molares superiores, que es bastante diferente. Los premolares ${ }^{2},{ }^{3} y^{4}$, presentan las dos aristas perpendiculares de la parte anterior de la cara externa, mas estrechas, y de tamaño igual, sin que la segunda tome la forma de una columna saliente como en la especie anterior; además la parte posterior externa de cada uno de estos dientes en vez de ser plana como en los del I. extensus es excavada por un surco perpendicular que viene inmediatamente detrás de la segunda arista, como sucede con los verdaderos molares de la especie mencionada.

Los verdaderos molares superiores del I. excavatus tienen las dos aristas perpendiculares de la parte anterior de la cara externa, casi confundidas en una sola, que toma el aspecto de una columna ancha en la que apenas se vé un pequeño vestigio de la ranura que en los premolares y en los molares de la otra especie la dividen en dos aristas. Detrás de esta columna, sobre la parte media de la cara externa, viene el surco perpendicular, mas estrecho y mas profundo que en los de la otra especie. Las muelas forman una série dentaria mas arqueada, pero mas corta, pues las siete muelas superiores juntas solo ocupan un espacio longitudinal en línea recta de 22 milimetros. La mandibula inferior se distingue por un tamaño un poco menor, por la parte sinfisaria mas comprimida transversalmente, por el diastema entre el canino y el premolar todavía bastante mas corto, y por los dos prismas que componen cada muela que son mas elípticos y de consiguiente menos prismáticos y menos oblicuos que en la otra especie".

English translation. This species was a third smaller in size than the previous one [Icochilus extensus], and it is distinguished from it by some characteristics of the external face of upper premolars and molars. P2-4 present the two antero-external perpendicular edges narrower and equal in size, the second edge that does not acquire the form 
of a projecting column as in the previous species; in addition, the postero-external region of each of these teeth, instead of being flat as in those of Ic. extensus, is excavated by a perpendicular groove that appears immediately behind the second edge, as it happens with the true molars of the previous species. M1-3 of Ic. excavatus have the two perpendicular edges of the anterior part of the external face almost confused in a single one, which takes on the appearance of a broad column in which barely a small vestige of a groove is visible, in the premolars and molars of the other species this is a groove that divides the column into two edges. A perpendicular depression appears behind this column, on the middle part of the external face of the tooth, and it is narrower and deeper than in the other species. The cheek tooth series is arranged in a more arched position, but it is shorter because the space occupied, in straight line, by the seven upper molars is only 22 millimetres. The mandible is distinguished by a quite smaller size, by its symphyseal region being more transversally compressed, by the diastema between the canine and the premolar that is still quite shorter, and by the two prisms that constitute each tooth which are more elliptical and, consequently, less prismatic and less oblique than in the other species.

Comments. Ameghino (1889: 472-473, plate 15: figs. 10-13) described and illustrated this taxon based on different characteristics of the upper and lower cheek teeth.

According to Ameghino's catalogue and Mones (1986), MACN-A 177 to MACN-A 180 are the type material of the species. The mandibular symphysis MACN-A 177 and the fragmented mandible MACN-A 178 match the original figures 12 and 13, respectively (Ameghino 1889: plate 15), which are herein reproduced (Figs. 3 G-K). Fortunately, we could locate the right maxilla MACN-A 9681, which matches figure 11 of the Atlas (Ameghino 1889 ) herein reproduced in Figure 3 G. On the other hand, even though the fragmented maxilla MACN-A 179 (Fig. $6 \mathrm{~F}$ ) and missing MACN-A 180, a mandibular or maxillary fragment according to the inventory, were not originally illustrated, they cannot be discarded as syntypes because both are part of the same lot as MACN-A 177 and MACN-A 178. Unfortunately, it was not possible to find an $\mathrm{m} 3$ that matches the figure 10 of the Atlas (Ameghino 1889: plate 15), but it is also considered as part of the type series of the species. Consequently, MACNA 177 to MACN-A 180 and MACN-A 9681 are the syntypes of Ic. excavatus.

\section{Icochilus undulatus Ameghino, 1889}

Holotype. MACN-A 373 (Fig. 3 L), an incomplete left maxilla with P3-M3.

Age and provenance of the type material. Santacrucian SALMA, early Miocene, Santa Cruz Province (Argentina).

Original description (Ameghino 1889: 473). "Esta especie era de talla intermediaria entre las dos precedentes [Icochilus extensus and Icochilus excavatus], de las que se distingue por los molares y premolares superiores de una conformación bastante distinta, particularmente sobre la cara externa. Los premolares superiores tienen las dos aristas perpendiculares de la parte anterior de la cara externa un poco mas anchas, pero mas bajas, sin levantarse sobre el plano de la cara externa como sucede con las dos especies precedentes, separadas por una ranura poco profunda, y la segunda arista seguida hacia atrás de una ranura idéntica á la precedente, de donde resulta que la cara externa de estos dientes presentan tres elevaciones perpendiculares poco elevadas, separadas por dos surcos poco profundos, que dan á la superficie externa de la muela un aspecto ligeramente ondulado, muy diferente del que caracteriza los mismos dientes del I. extensus y el I. excavatus. Los verdaderos molares difieren todavía mas que los premolares, pues las dos aristas externas anteriores están completamente confundidas en una sola columna convexa bastante ancha; cada muela superior presenta así sobre el lado externo dos columnas ó lóbulos perpendiculares poco salientes que corresponden á los dos lóbulos internos, estando separados por una pequeña depresión perpendicular poco profunda, opuesta al pliegue y profundo surco perpendicular del lado interno. Las últimas muelas superiores, y sobre todo el último verdadero molar, se distingue por una corona muy comprimida. La serie dentaria era casi recta".

English translation. Intermediate in size between the two previous species (Icochilus extensus and Icochilus excavatus), from which it is distinguished by presenting upper premolars and molars with a quite different conformation, particularly on the external face. Upper premolars have the two antero-external perpendicular edges separated by a shallow groove, which are a little wider, but lower, without rising above the plane of the external face, as it happens in the two preceding species; behind the second edge there is an identical depression to that of the preceding one, leading to the external face of these teeth have three slightly elevated perpendicular elevations, 
separated by two shallow sulci; as a result, the external surface of the premolars is slightly undulated, what markedly differs from Ic. extensus and Ic. excavatus. True molars differ even more than the premolars as the two antero-external edges are completely confused in a single, very wide and convex column; thus, each upper molar has two perpendicular columns or lobes on the external side, which are not very prominent and correspond to the two internal lobes, being separated from each other by a small and shallow perpendicular depression, opposite to the fold and the deep perpendicular groove of the inner side. The last upper molars, particularly M3, are distinguished by a very compressed crown. The dental series was almost straight.

(A)

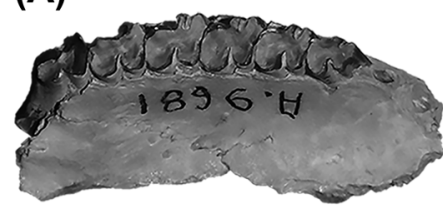

(B)

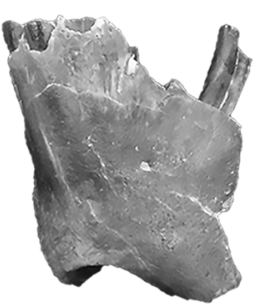

(C)

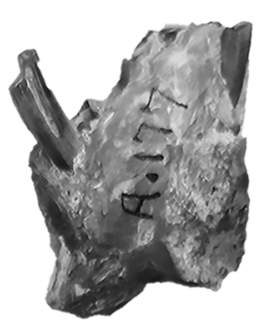

(D)

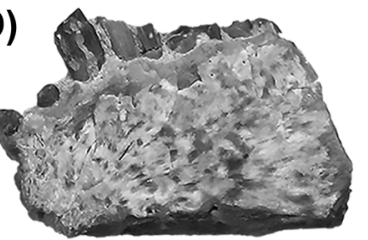

(E)

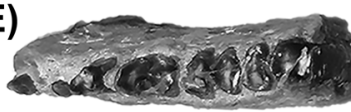

(F)

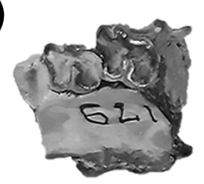

(G)

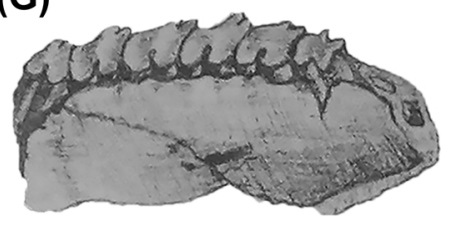

(H)

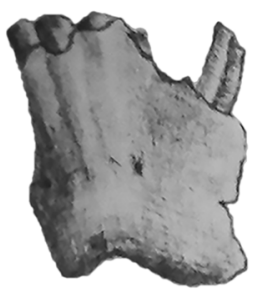

(I)

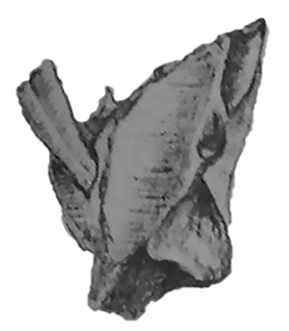

(J)

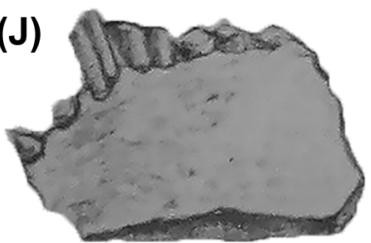

(N)

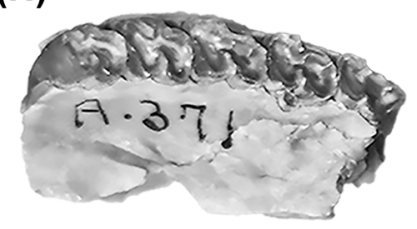

(0)

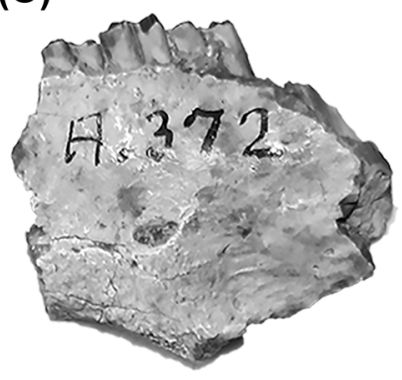

(P)

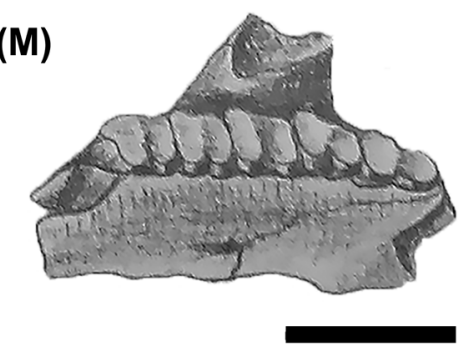

(L)
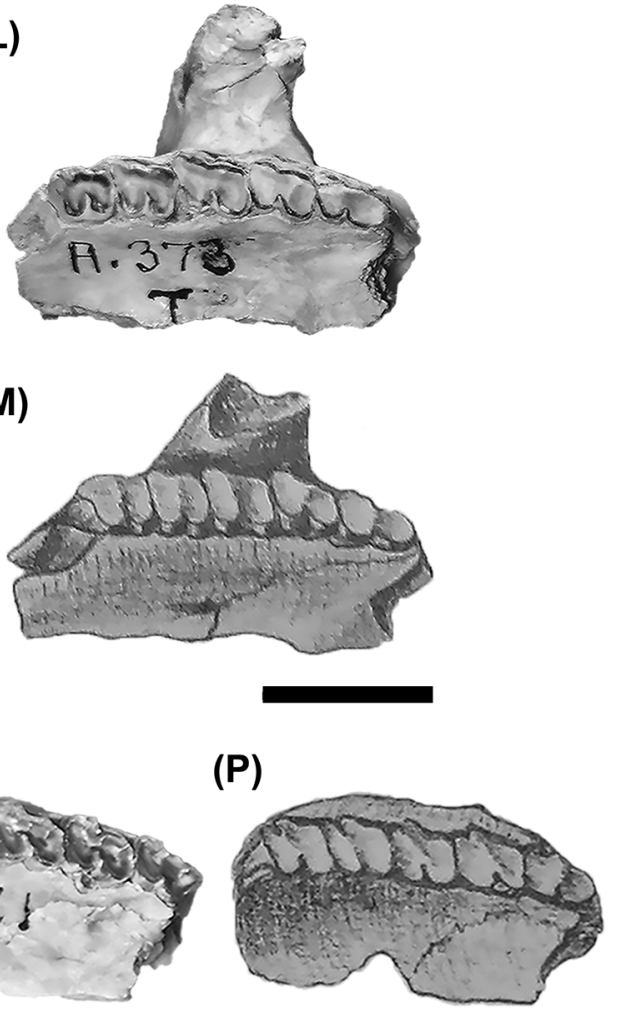

(Q)

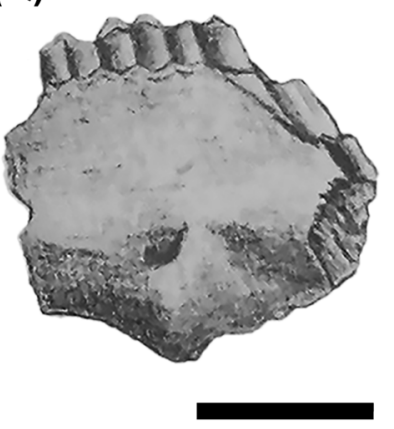

FIGURE 3. Icochilus excavatus, syntype MACN-A 9681, right maxilla with alveoli of C and dP1 and complete P2-M3, in occlusal view (A); syntype MACN-A 177, broken symphysis, in labial (B) and lingual (C) views; syntype MACN-A 178, fragmented mandible with c-m1, in labial (D) and occlusal (E) views; syntype MACN-A 179, fragmented right maxilla with two molariforms, in occlusal view (F); reproductions of figures $11(\mathbf{G}), 12(\mathbf{H}), 12$ a (I), 13 (J) and 13a (K) from Ameghino (1889, plate 15). Icochilus undulatus, holotype MACN-A 373, left maxilla with P3-M3, in occlusal view (L); reproduction of figure 14 (M) from Ameghino (1889, plate 15). Icochilus rotundatus, holotype MACN-A 371, incomplete left maxilla with P3-M3, in occlusal view (N); holotype MACN-A 372, left mandibular fragment with p3-m1, in occlusal view (O); reproductions of figures $15(\mathbf{P})$ and $16(\mathbf{Q})$ from Ameghino $(1889$, plate 15). Scale bar $=10 \mathrm{~mm}$. 
Comments. Ameghino (1889: 473) founded this species based on a maxillary fragment illustrated in his Atlas (Ameghino 1889, plate 15: fig. 14). According to Ameghino's catalogue and Mones (1986), the incomplete maxilla MACN-A 373 is the type specimen of the species. This material matches the original diagnosis and illustration provided by Ameghino (1889, plate 15: fig. 14), herein reproduced (Fig. $3 \mathrm{M}$ ), and it is confirmed as the holotype of Ic. undulatus.

\section{Icochilus rotundatus Ameghino, 1889}

Syntypes. MACN-A 371 (Fig. 3 N), incomplete left maxilla with P3-M3; MACN-A 372 (Fig. 3 O), left mandibular fragment with $\mathrm{p} 3-\mathrm{m} 1$.

Age and provenance of the type material. Santacrucian SALMA, early Miocene, Santa Cruz Province (Argentina).

Original description (Ameghino 1889: 473-474). "La talla de esta especie es apenas un poco menor que la del I. extensus, y con muelas que reúnen en parte los caractéres de las tres precedentes. Los premolares superiores tienen las dos aristas perpendiculares dé la parte anterior de la cara externa, apenas un poco desiguales, la segunda algo mas desarrollada que la primera, pero sin tomar la forma de columna saliente que presenta en los premolares del I. extensus. Además, detrás de la segunda

arista existe la depresión ó surco perpendicular medio, que falta en los mismos dientes de la especie mencionada. Los verdaderos molares presentan las dos aristas anteriores casi confundidas, con la ranura que las separa poco profunda ó rudimentaria, pero sin que se levanten tanto encima de la superficie de la cara externa como en el I. excavatus. Detrás de esta arista, viene la depresión perpendicular mediana, bastante ancha, pero poco profunda. La última muela superior es apenas un poco mas pequeña que la penúltima y casi del mismo ancho. La série dentaria es ligeramente arqueada. [...] De la mandíbula inferior conozco un fragmento de la rama horizontal del lado izquierdo, con los dos últimos premolares y el primer verdadero molar. Cada muela consta de dos prismas elípticos casi iguales, apenas un poco mas angostos sobre el lado interno, con su diámetro mayor en sentido transversal. El $p_{\cdot_{3}}$ tiene $0^{m} 0035$ de diámetro ántero-posterior y $0^{m} 0025$ de diámetro transverso. El $p_{\cdot 4}$ y el m. ${ }_{1}$ tienen cada uno 4 milímetros de diámetro ántero-posterior y 3 milímetros de diámetro transverso. El agujero mentoniano posterior es de tamaño mucho mayor que en las otras especies, pero está igualmente colocado debajo de la parte anterior del p. . La rama horizontal debajo del p. ${ }_{4}$ tiene 17 milimetros de alto".

English translation. This species is slightly smaller in size than Ic. extensus, and presents cheek teeth that partially combine the characters of the preceding three species. Upper premolars have the two antero-external perpendicular edges slightly dissimilar; the second is somewhat more developed than the first, but without taking the form of a protruding column as in Ic. extensus. In addition, behind the second edge there is a median and perpendicular depression or sulcus, which is absent in the same teeth of the already mentioned species. True upper molars present the two anterior edges nearly confused in a single column, with the groove that separates them being shallow or rudimentary, but without rising above the surface of the external face as much as in Ic. excavatus. Behind this edge, there is the median perpendicular depression fairly broad but shallow. The last upper molar is just a little smaller than the second molar and almost of the same width. The dental series is slightly arched. [...] I know from the mandible a fragment of the left horizontal ramus, with the last two premolars and the first true molar. Each cheek tooth consists of two almost equal and elliptical prisms, just a little narrower on the inner side, with its greater diameter in transverse direction. The $\mathrm{p} 3$ has $0.0035 \mathrm{~m}$ of antero-posterior diameter and $0.0025 \mathrm{~m}$ of transverse diameter. The $\mathrm{p} 4$ and $\mathrm{m} 1$ have 4 millimetres of antero-posterior diameter and 3 millimetres of transverse diameter. The posterior mental foramen is much larger in size than in the other species, but it is also placed below the anterior part of $\mathrm{p} 4$. The horizontal ramus below $\mathrm{p} 4$ is 17 millimetres high.

Comments. Ameghino (1889: 473-474) erected and described this species based on a maxilla and a mandible, both incomplete (Ameghino 1889, plate 15: figs. 15-16). Later, Ameghino (1894a: 15) extended the original description based on a skull that he did not illustrate.

According to Ameghino's catalogue and Mones (1986), the incomplete skull MACN-A 3588 is the type specimen. MACN-A 3588 corresponds to the skull described by Ameghino (1894a), because it lacks the upper canine and exhibits a long diastema between $\mathrm{I} 3$ and $\mathrm{dP} 1$. However, it does not match any of the illustrations provided by Ameghino (1889, plate 15: figs. 15-16) and does not exhibit the diagnostic characteristics stated in the original description. Consequently, MACN-A 3588 is neither the holotype nor part of the type series of the species. 
On the other hand, MACN-A 371, left maxillary fragment with P3-M3, and MACN-A 372, left mandibular fragment with $\mathrm{p} 3-\mathrm{m} 1$, match the original illustrations (Ameghino 1889: plate 15, figs. 15-16), which are herein reproduced in Figures. $3 \mathrm{P}-\mathrm{Q}$. It is worth mentioning that it cannot be guaranteed that both specimens belong to the same individual because they do not articulate to each other and there is no mention of this in Ameghino's catalogue — as he used to do when this was the case—. Therefore, MACN-A 370 and MACN-A 371 are considered here as the syntypes of Ic. rotundatus.

\section{Icochilus robustus Ameghino, 1891}

Holotype. MACN-A 3454 (Fig. 4A) to MACN-A 3505, complete skull and mandible of the same individual, with associated postcranial elements.

Age and provenance of the type material. Santacrucian SALMA, early Miocene, Santa Cruz Province (Argentina).

Original description (Ameghino 1891: 393). "Del tamaño de Icochilus extensus, del que se distingue por el cráneo más ancho y por los frontales que se prolongan adelante entre los nasales".

English translation. Of the same size as Icochilus extensus, from which it is distinguished by presenting a wider skull and the frontals extended forward between the nasals.

Comments. Ameghino (1891: 393, figs. 95-97) briefly described this species in a footnote, stating that he had the entire skeleton of an individual. He also illustrated a foot, a right hand and an almost complete skull.

According to Ameghino's catalogue and Mones (1986), MACN-A 3454 to MACN-A 3505, an almost complete individual, constitute the type specimen of the species. MACN-A 3454 is indeed the illustrated complete skull (Ameghino 1891: fig. 97), herein reproduced (Fig. 4 B), although it has suffered many breaks. Regarding the right manus and foot, only some elements (basipodia, metapodia and phalanges) are present. At the beginning of the current study, all of these materials were in different uncovered containers, so it is assumed that different elements have been missed over the years. Therefore, MACN 3454 to MACN-A 3505 are confirmed as elements of the holotype of Ic. robustus.

\section{Icochilus senilis Ameghino, 1894a}

Holotype. MACN-A 3596 (Fig. 4 C), incomplete skull, MACN-A 3597 (Fig. 4 D), complete mandible, and MACN-A 3598 to MACN-A 3630, postcranial elements, all of them from the same individual.

Age and provenance of the type material. Santacrucian SALMA, early Miocene, Santa Cruz Province (Argentina).

Original description (Ameghino 1894a: 15). "Cette espèce est de la taille de l'I. extensus, mais un peu plus robuste; elle se distingue facilement par la deuxième prémolaire inférieure qui n'est pas bilobée, mais de contour elliptique et par conséquent sans sillon vertical, ni sur la face interne ni sur l'externe. La troisième et quatrième prémolaire inférieure ainsi que les vraies molaires, sont plus larges que dans les autres espèces. La deuxième prémolaire supérieure est aussi de contour elliptique et sans sillon. Il y a un diastème assez long entre la canine inférieure et la première prémolaire. Longueur des sept molaires inférieures, $32 \mathrm{~mm}$ ".

English translation. This species is of the size of Ic. extensus, but it is a little more robust; it is easily distinguished by the second lower premolar that is not bilobated but elliptical and, subsequently, without internal and external vertical grooves. The third and fourth lower premolars, as well as the true molars, are wider than in the other species. The second upper premolar is also elliptical and without groove. There is a rather long diastema between the lower canine and the first premolar. Length of the seven lower molars, $32 \mathrm{~mm}$.

Comments. Ameghino (1894a) did not illustrate any specimen of this species. According to Ameghino's catalogue and Mones (1986), MACN-A 3596 to MACN-A 3630, an almost complete individual, constitute the type specimen of this species. The mandible MACN-A 3597 and the skull MACN-A 3596 present the respective p2 and P2 elliptical in cross section with very shallow lingual and labial grooves. In addition, the dimensions of MACN-A 3597 (length of the diastema $\mathrm{c}-\mathrm{dp} 1=2 \mathrm{~mm}$; length of the lower tooth row $=32 \mathrm{~mm}$ ) match those provided by Ameghino (1894a). Therefore, MACN-A 3596 to MACN-A 3630 are confirmed as the holotype of Ic. senilis. 

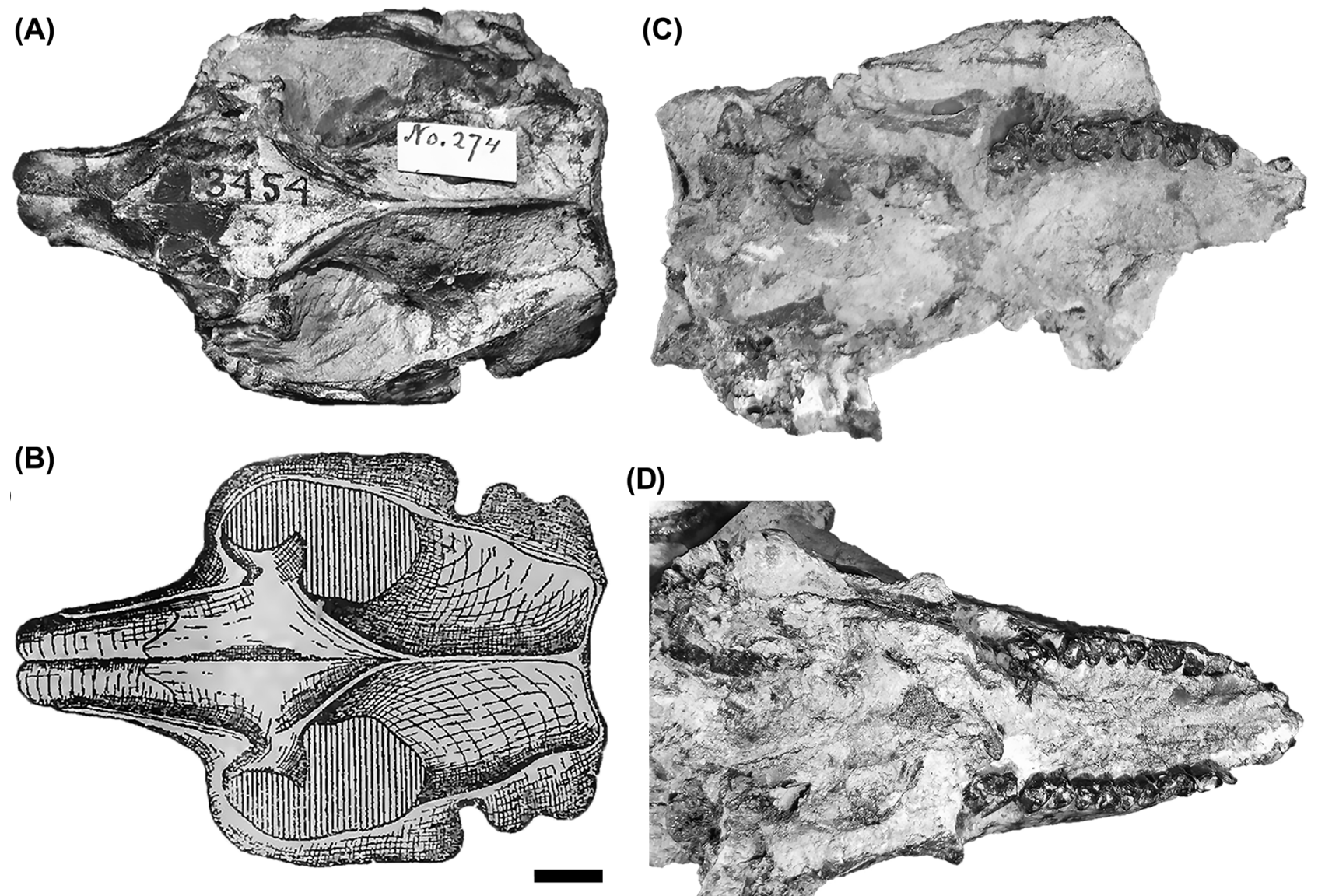

(D)

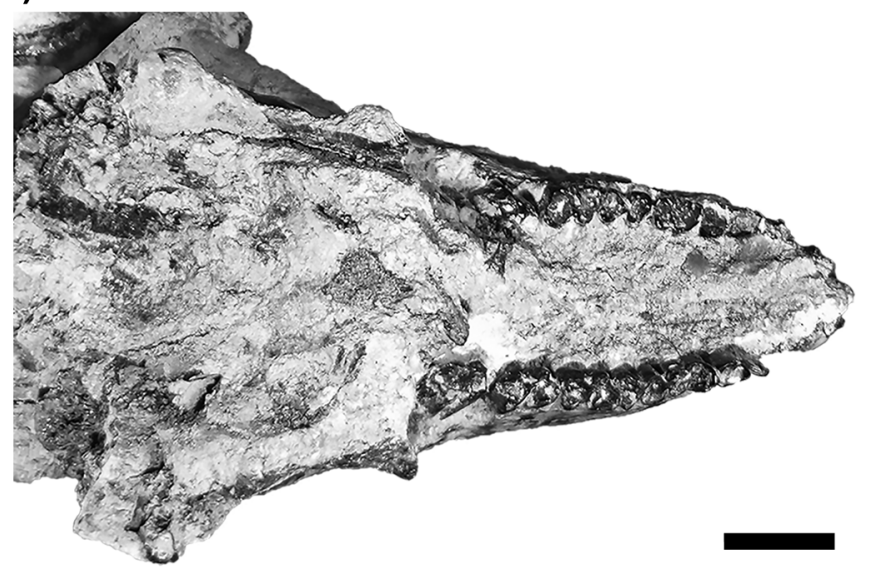

FIGURE 4. Icochilus robustus, holotype MACN-A 3454, skull, in dorsal view (A); reproduction of figure 97 (B) from Ameghino (1891). Icochilus senilis, holotype MACN-A 3596, incomplete skull, in ventral view (C); holotype MACN-A 3597, incomplete mandible, in dorsal view (D). Scale bar $=10 \mathrm{~mm}$.

\section{Icochilus lamellosus Ameghino, 1894a}

Holotype. MACN-A 3631 (Fig. 5 A), incomplete skull with complete dentition.

Age and provenance of the type material. Santacrucian SALMA, early Miocene, Santa Cruz Province (Argentina).

Original description (Ameghino 1894a: 15-16). "Espèce de petite taille. La canine supérieure est bien développée, de la même grandeur et à peu près de la même forme que l'incisive externe, étant séparées l'une de l'autre par un petit diastème ; ces deux dents sont comprimées latéralement et ont la forme de lames tranchantes. L'incisive externe ou troisième, est séparée de la deuxième par un diastème assez long; un autre diastème un peu plus long sépare la première prémolaire de la canine. La p $p^{l}$ est placée contre la $p^{2}$ et porte un sillon vertical à son angle antérieur externe. Longueur du bord antérieur de l'i au bord postérieur de la m³, 37 mm".

English translation. Species of small size. The upper canine is well developed, of the same size and nearly the same form as the external incisor, being separated from each other by a small diastema; these two teeth are laterally compressed and have the appearance of cutting blades. The external incisor, or third, is separated from the second by a rather long diastema; another slightly longer diastema separates the first premolar from the canine. The P1 is placed against P2 and has a vertical groove at its antero-external angle. Length from the anterior edge of I1 to the posterior border of $\mathrm{m} 3,37 \mathrm{~mm}$.

Comments. Ameghino (1894a) did not add any illustration to the description of this species. According to Ameghino's catalogue and Mones (1986), the incomplete skull MACN-A 3631 is the type specimen. MACN-A 
3631 exhibits a well-developed upper canine that is subequal to I3 - being both teeth laterally compressed-, and the diastemata I2-3, I3-C and C-dP1 mentioned by Ameghino (1894a). Even though the author did not indicate the dimensions of these discontinuities, he established relative differences in size, which resemble those obtained in the material (length of diastema I2-3 = left, $0.9 \mathrm{~mm}$ and right, $1.4 \mathrm{~mm}$; length diastema I3-C: left, $0.4 \mathrm{~mm}$ and right, $0.8 \mathrm{~mm}$; length of diastema $\mathrm{C}-\mathrm{dP} 1$ : left, $2.6 \mathrm{~mm}$ and right, $2.2 \mathrm{~mm}$ ). The length of $\mathrm{I} 1-\mathrm{M} 3$ series (38 $\mathrm{mm})$ also matches the value provided by Ameghino (1894a). Therefore, MACN-A 3631 is confirmed as the holotype of Ic. lamellosus.

\section{Icochilus trilineatus Ameghino, 1894a}

Syntypes. MACN-A 3633 (Fig. 5 B), fragmented left maxilla with M2; and MACN-A 3651 to MACN-A 3657 (Figs. 5 C-H), isolated cheek teeth.

Age and provenance of the type material. Santacrucian SALMA, early Miocene, Santa Cruz Province (Argentina).

Original description (Ameghino 1894a: 16). "Cette espèce est de la même taille que l' I. extensus, dont elle se distingue facilement aussi bien que des autres espèces, par la forme de ses molaires et prémolaires supérieures. Chacune de ces dents porte sur sa face externe un sillon large et profond qui la divise en deux lobules, et sur chaque lobule il y a un sillon étroit et profond qui le divise en deux colonnettes verticales; on voit ainsi sur la face externe de chaque dent, quatre colonnettes séparées par trois sillons, dont celui du milieu beaucoup plus large et les autres deux très étroits".

English translation. This species has the same size as Ic. extensus, from which it is easily distinguished, as well as from the other species, by the morphology of its upper molars and premolars. Each tooth presents a broad and deep groove on its external face, which divides it into two lobules, and on each lobule there is a narrow and deep groove that divides it into two vertical columns; as a result, the external face of each tooth exhibits four columns separated by three grooves, the second being the widest whereas the other two are very narrow.

Comments. Ameghino (1894a) did not illustrate this species. According to Ameghino's catalogue and Mones (1986), MACN-A 3633, a small maxillary fragment with M2, is the type specimen of the species. The ectoloph of this M2 exhibits three perpendicular grooves, one in the middle and one at each lateral lobe, resulting in an ectoloph with four columns as indicated by Ameghino (1894a). Nonetheless, when describing the species, Ameghino (1894a: 16) alluded to the form of its upper molars and premolars, which implies that he had more than one tooth at hand, and therefore MACN-A 3633 cannot be the only type specimen. In this context, in the Ameghino Collection, the lot MACN-A 3651 to MACN-A 3657 contains six isolated teeth (instead of seven as corresponding inventory numbers), five of which (two M3, and three upper molariforms, probably P4 and/or M1/2) show the characteristics mentioned by Ameghino (1894a); thus, we consider them as part of the type series. As the specimens in the lot lack individual labels, it is not possible to identify which is the missing seventh tooth. Therefore, MACN-A 3633 and MACN-A 3651 to MACN-A 3657 (one currently missing) are considered the syntypes of Ic. trilineatus.

\section{Icochilus anomalus Ameghino, 1894a}

Holotype. MACN-A 3634 (Fig. 5 I), mandibular right fragment with c and p2-3, currently missing.

Age and provenance of the type material. Santacrucian SALMA, early Miocene, Santa Cruz Province (Argentina).

Original description (Ameghino 1894a: 16). "De la même taille que l'Icochilus extensus. Cette espèce se distingue facilement par l'atrophie et la disparition de plusieurs dents. L'incisive inférieure externe est très petite. La canine inférieure est extrêmement petite, et isolée en avant et en arrière par des diastèmes assez longs, tandis que dans presque toutes les autres espèces du même genre cette dent est au contraire bien développée et couchée en avant sur les incisives, dont elle en a la forme. La première prémolaire inférieure a complètement disparu. La deuxième prémolaire inférieure est bien développée et avec deux sillons perpendiculaires opposés, l'un interne et l'autre externe". 


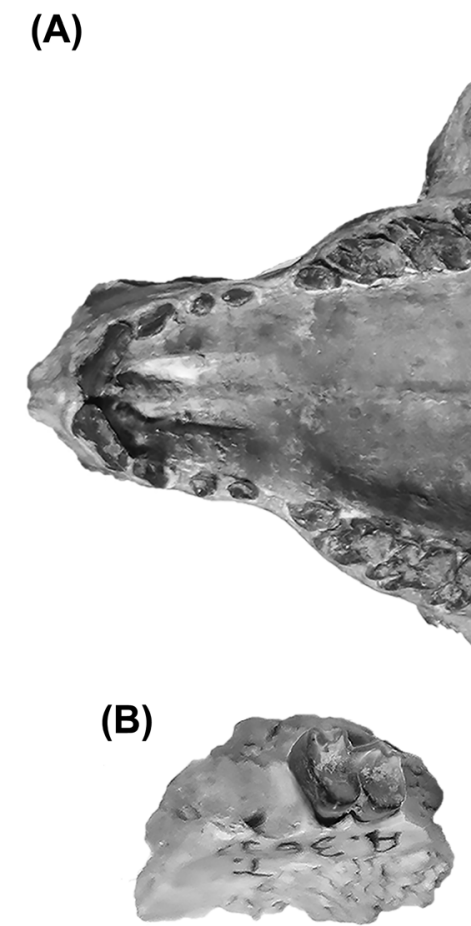

(E)

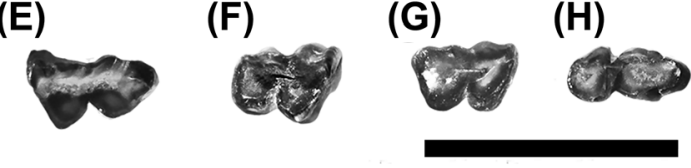

(l)

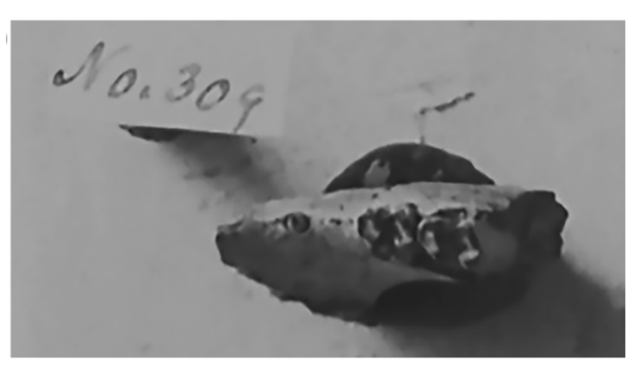

(D)
(J)

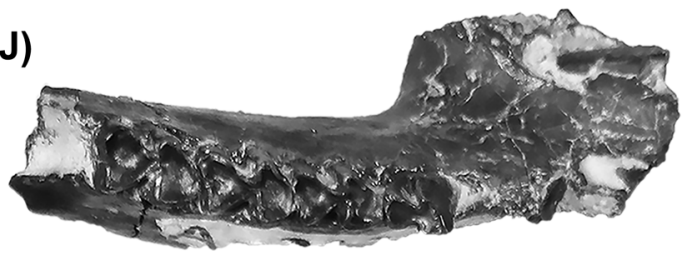

(K)
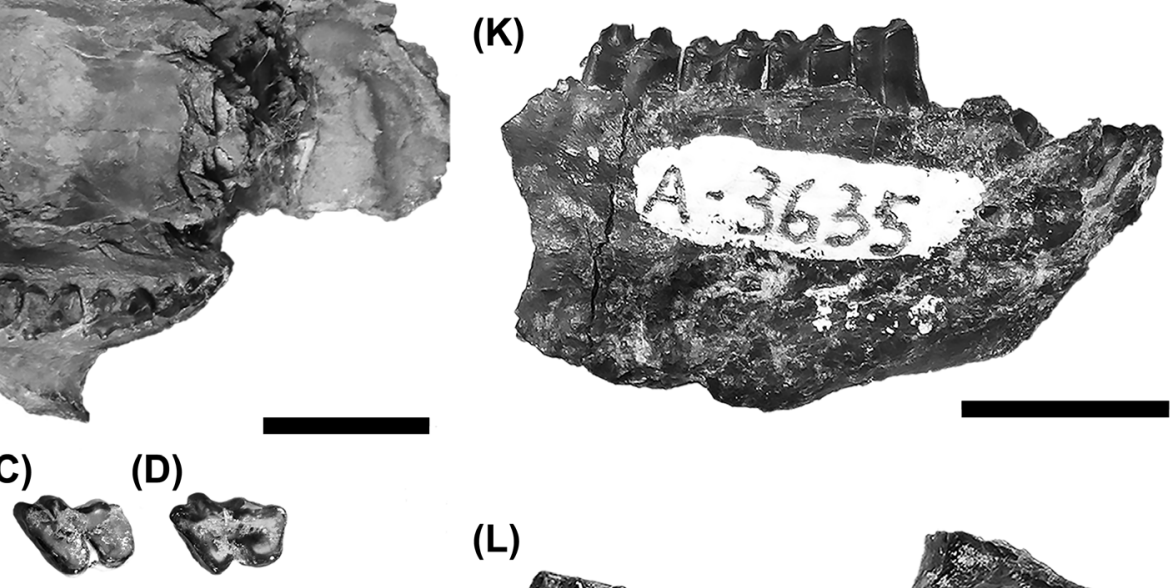

(L)

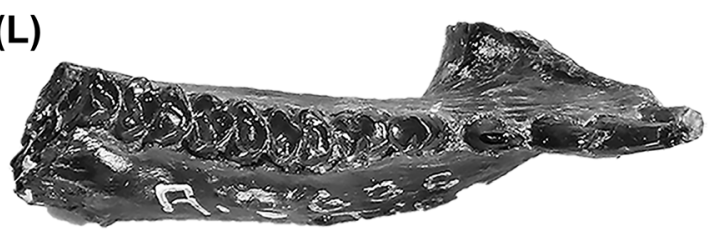

(M)

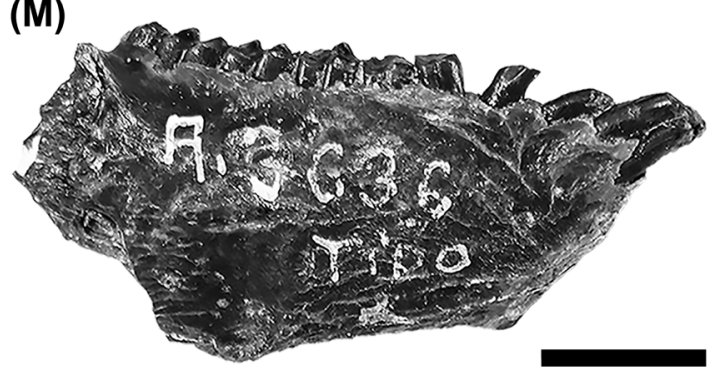

FIGURE 5. Icochilus lamellosus, holotype MACN-A 3631, incomplete skull, in ventral view (A). Icochilus trilineatus, MACN-A 3633, left M2, in occlusal view (B); MACN-A 3651 to MACN-A 3657 in occlusal view (C-H): left P4 or M1/2 (C), left P4 or M1/2 (D), left M3 (E), right P4 or M1/2 (F), right M3 (G), right m3 (H). Icochilus anomalus, detail of photograph of the holotype MACN-A 3634 from Scott's catalogue (I). Icochilus truncus, holotype MACN-A 3635, right fragmented mandible with alveoli of $\mathrm{i} 1-\mathrm{dp} 1$ and complete $\mathrm{p} 2-\mathrm{m} 1$, in occlusal (J) and lateral (K) views. Icochilus crassiramis, holotype MACN-A 3636, right mandibular fragment with i2-m3, in occlusal (L) and lateral (M) views. Scale bar $=10 \mathrm{~mm}$.

English translation. With the same size as Icochilus extensus. This species is easily distinguished by the atrophy and disappearance of several teeth. The external lower incisor is very small. The lower canine is extremely small and is anteriorly and posteriorly isolated by rather long diastemata, whereas in almost all the other species of the genus this tooth is instead, well developed and leaned on the incisors. The first lower premolar is absent. The second lower premolar is well developed and exhibits two opposite, internal and external, perpendicular grooves.

Comments. Ameghino (1894a) described this species, but did not illustrate any specimen of it. Ameghino's catalogue and Mones (1986) indicate the mandibular fragment MACN-A 3634 as the type specimen of the species. This is the only material assigned to this species in Ameghino's catalogue, but unfortunately, it could not be found in the Ameghino Collection. Nevertheless, when studying Scott's photographic catalogue published by Vizcaíno et al. (2017), it was possible to identify the photograph No. 309 (Fig. 5 I) as the fragmented mandible assigned to Ic. anomalus by Ameghino (1894a). That specimen matches the original description, because it exhibits a reduced lower canine, diastemata anterior and posterior to this tooth, and the absence of dp1. Taking into consideration that 
MACN-A 3634 was the only specimen assigned to this species, it is highly probable that the photograph No. 309 corresponds to the currently missing specimen. Therefore, if this was the case, it should be considered the holotype of Ic. anomalus, but unfortunately it has not been located.

\section{Icochilus truncus Ameghino, 1894a}

Holotype. MACN-A 3635 (Figs. $5 \mathrm{~J}-\mathrm{K}$ ), right fragmented mandible with alveoli of i1-dp1 and the series p2-m1.

Age and provenance of the type material. Santacrucian SALMA, early Miocene, Santa Cruz Province (Argentina).

Original description (Ameghino 1894a: 16). "A peu près de la même taille que l'I. extensus. Elle se distingue par la présence de la première prémolaire inférieure très petite, et par l'absence de la canine inférieure. A la place de la canine il y a un diastème assez étendu qui sépare l'incisive externe de la première prémolaire".

English translation. Size almost the same as Ic. extensus. It is distinguished by the presence of a very small first lower premolar, and by the absence of the lower canine. In the place of the lower canine there is a rather extensive diastema that separates the external incisor from the first premolar.

Comments. Ameghino (1894a) did not add any illustration to the brief description of I. truncus. According to Ameghino's catalogue and Mones (1986), MACN-A 3635, a broken symphysis with a fragmented right mandibular ramus, is the type material of the species. This specimen has a small alveolus of $\mathrm{dp} 1$ and a diastema between $\mathrm{i} 3$ and dp1, whose length $(2.2 \mathrm{~mm}$ ) falls within the range (1 to $3 \mathrm{~mm}$ ) that Ameghino provided for any gap between adjacent teeth (Ameghino 1894a: 15-18). These characteristics are consistent with Ameghino's (1894a) description and, consequently, MACN-A 3635 is confirmed as the holotype of Ic. truncus.

\section{Icochilus crassiramis Ameghino, 1894a}

Holotype. MACN-A 3636 (Figs. 5 L-M), right mandibular fragment with i2-m3.

Age and provenance of the type material. Santacrucian SALMA, early Miocene, Santa Cruz Province (Argentina).

Original description (Ameghino 1894a: 16-17). "De la même taille que 1 'I. extensus. Cette espèce se distingue très bien par la première prémolaire inférieure qui a la forme d'une canine bien développée, étant isolée en avant et en arrière par des diastèmes assez longs. La canine inférieure a la forme d'une incisive, étant couchée en avant sur l'incisive externe. La deuxième prémolaire inférieure est elliptique, sans sillon perpendiculaire interne; de celui du côté externe on en voit à peine des traces".

English translation. Same size as Ic. extensus. This species is very well distinguished by its first lower premolar that has the morphology of a well-developed canine, being anteriorly and posteriorly isolated by rather long diastemata. The lower canine is incisor-shaped, anteriorly leaned on the external incisor. The second lower premolar is elliptical, without internal perpendicular groove; no trace of external groove is visible.

Comments. Ameghino (1894a) did not illustrate any specimen of this species. According to Ameghino's catalogue and Mones (1986), MACN-A 3636, a right mandibular ramus, is the type specimen. This material matches the original description (Ameghino 1894a) because it exhibits a canine-like dp1 separated by anterior $(\mathrm{L}=$ $1.5 \mathrm{~mm})$ and posterior $(\mathrm{L}=1.2 \mathrm{~mm})$ diastemata, and an elliptical $\mathrm{p} 2$ with very shallow ectoflexid and entoflexid. These characteristics match Ameghino's (1894a) description and, as a result, MACN-A 3636 is confirmed as the holotype of Ic. crassiramis.

\section{Icochilus multidentatus Ameghino, 1894a}

Lectotype (this contribution). MACN-A 3637 (Fig. 6 A), right maxilla with alveolus of an extra tooth and C, and complete series dP1-P2-M3.

Paralectotypes (this contribution). MACN-A 3638 (Figs. 6 B-C), right mandibular fragment with dp1-4 and $\mathrm{m} 1-3$. 

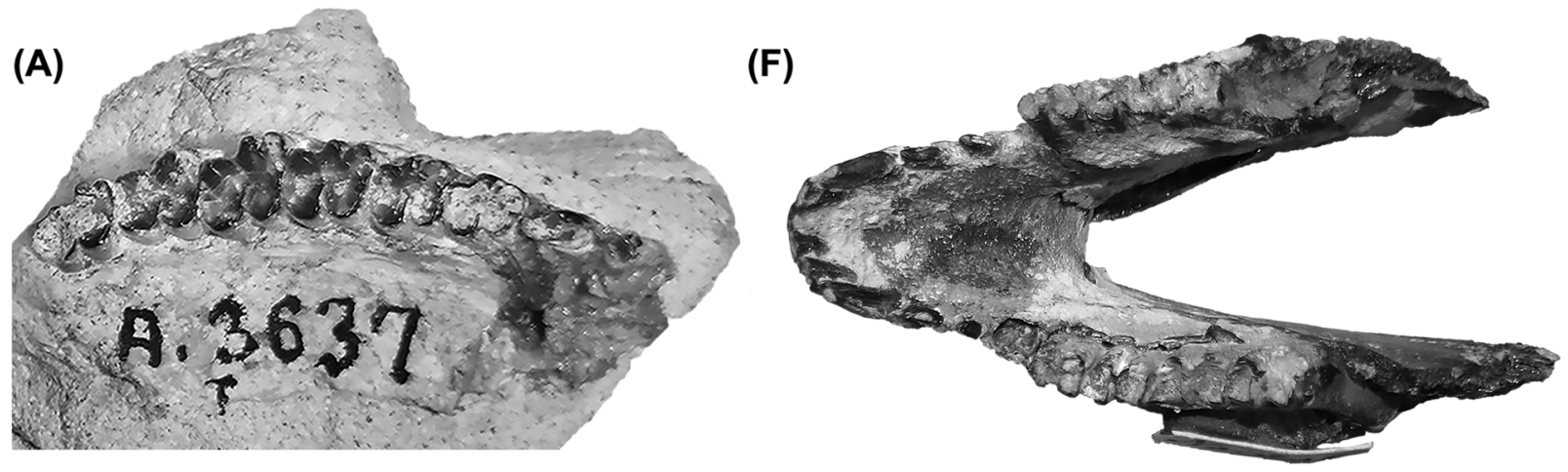

(B)
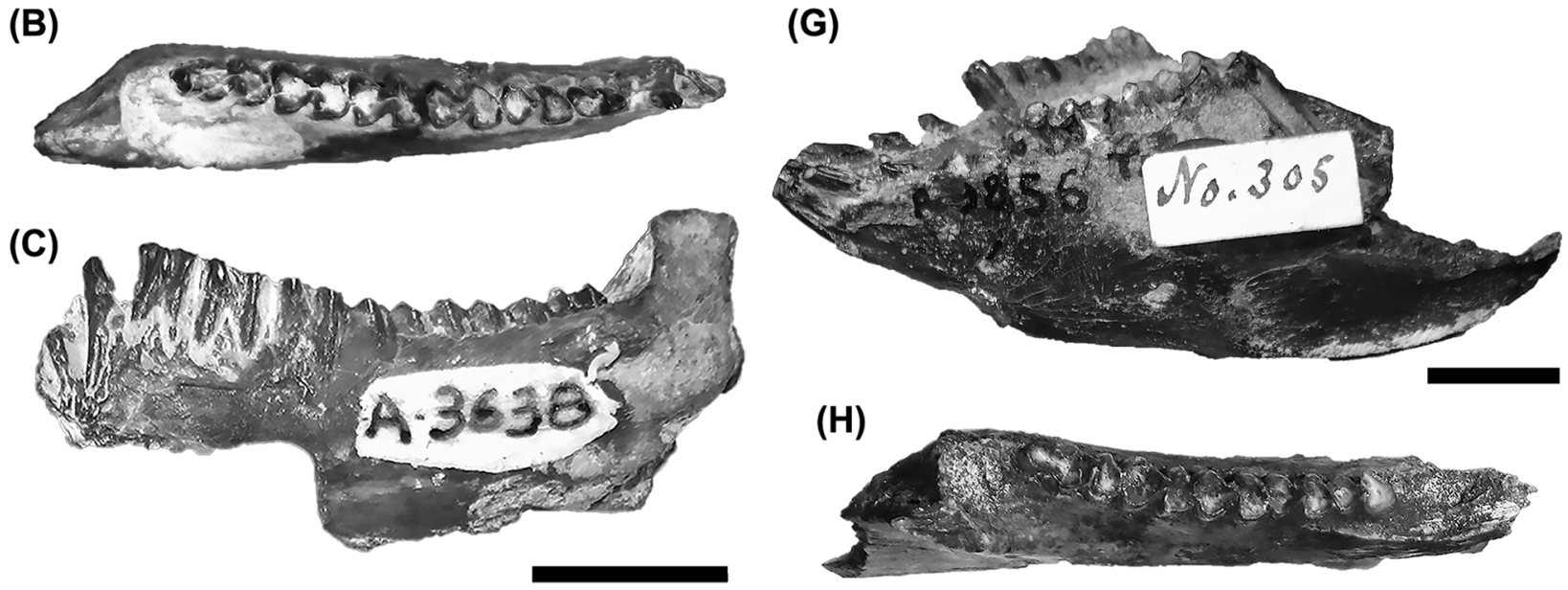

(D)

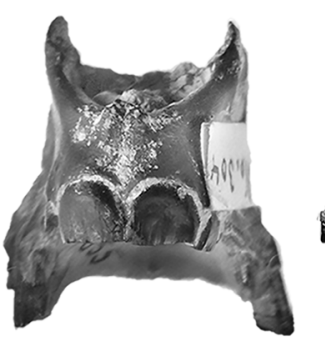

(E)

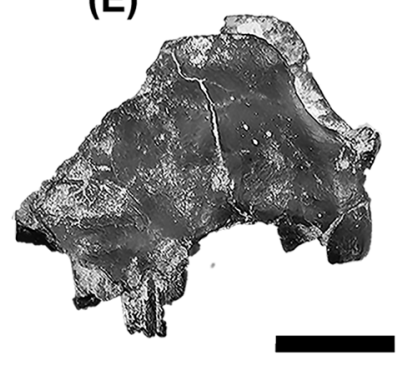

(I)

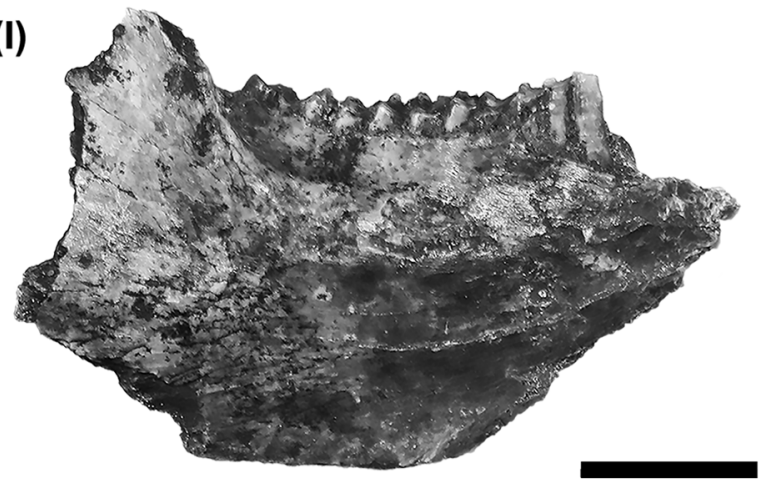

FIGURE 6. Icochilus multidentatus, lectotype MACN-A 3637, right maxilla with alveolus of extra tooth and C and dP1-M3, in occlusal view (A); paralectotype MACN-A 3638, right mandibular fragment with dp1-4 and m1-3, in oclusal (B) and lingual (C) views. Icochilus hegetotheroides, holotype MACN-A 9855, incomplete skull, anterior view of the premaxilla with labial view of both I1 (D) and right lateral view (E); holotype MACN-A 9856, incomplete mandible, in occlusal (F) and left lateral (G) views. Icochilus ulter, holotype MACN-A 11601, right mandibular fragment with p3-m3, in oclusal (H) and labial (I) views. Scale bar $=10 \mathrm{~mm}$.

Age and provenance of the type material. Santacrucian SALMA, early Miocene, Santa Cruz Province (Argentina).

Original description (Ameghino 1894a: 17). "De taille assez petite; elle se distingue pour avoir huit molaires en haut et en bas, de chaque côté, dont les cinq antérieures sont des prémolaires. À la mâchoire supérieure, la canine et les deux premières prémolaires sont très petites et en série continue avec les autres dents. A la mâchoire inférieure, les deux premières prémolaires ont la forme de petites canines et la deuxième est séparée de la troisième par un petit diastème. Les deux premières prémolaires inférieures et la canine se suivent sans diastème. Les huit molaires supérieures occupent une longueur de $28 \mathrm{~mm}$ ".

English translation. Quite small; it is distinguished in having eight upper and lower cheek teeth, of which the 
anterior five are premolars. In the maxilla, the canine and the first two premolars are very small and placed in a continuous series with the other cheek teeth. In the mandible, the first two premolars look like small canines and the second is separated from the third by a small diastema. The first two lower premolars and the canine follow each other without diastemata. The eight upper cheek teeth occupy a length of $28 \mathrm{~mm}$.

Comments. Ameghino (1894a) did not figure any material of this species. According to Ameghino's catalogue and Mones (1986), MACN-A 3637, a right maxilla, and MACN-A 3638, an incomplete right mandibular ramus, are the type specimens of the species. MACN-A 3637 matches the original description because it exhibits a broken alveolus that indicates the presence of an extra tooth, which is discarded as I3 because there is no trace of the premaxilla-maxilla suture. Regarding lower dentition, MACN-A 3638 also matches the original diagnosis as it presents what can be considered at first sight an extra alveolus, as well as $\mathrm{c}$ and the first premolar (according to Ameghino) without separation, whereas there is a diastema between the second and third premolar of the tooth row. Consequently, both materials are confirmed as types, but due to the fact that they belong to two different individuals in two different ontogenetic stages-MACN-A 3637 presents all permanent dentition, whereas MACN-A 3638 exhibits deciduous premolars (dp2-4) - both are considered as syntypes of Ic. multidentatus. In addition, the comparison with other specimens of Icochilus allows us to recognize the extra lower alveolus of MACN-A 3638 as corresponding to i3; in consequence, we select this specimen as the lectotype of Ic. multidentatus as it undoubtedly exhibits the main diagnostic characteristic — extra tooth — of the species, and then MACN-A 3638 becomes the paralectotype (ICZN 2000: Art. 73.2.2).

\section{Icochilus curtus Ameghino, 1894a}

Holotype. Not located, probably lost.

Age and provenance of the type material. Santacrucian SALMA, early Miocene, Santa Cruz Province (Argentina).

Original description (Ameghino 1894a: 17). "De la même taille que l'I. extensus. Cette espèce se distingue facilement par le grand raccourcissement de la dernière molaire inférieure qui est à peine un peu plus longue que l'avant-dernière, et par son lobe postérieur qui est convexe sur le côté externe, sans vestige du sillon perpendiculaire qu'on voit sur la même dent des autres espèces. La dernière molaire inférieure a près de $5 \mathrm{~mm}$. de longueur, et les deux dernières molaires occupent un espace de $9 \mathrm{~mm}$. de long".

English translation. With the same size as Ic. extensus. This species is easily distinguished by the great shortening of the last lower molar, which is just a little longer than $\mathrm{m} 2$, and by its posterior lobe that is convex on the external side and it does not exhibit the perpendicular groove seen on the same tooth in the other species. The last lower molar is nearly $5 \mathrm{~mm}$ long, and the last two molars occupy a space of $9 \mathrm{~mm}$.

Comments. Ameghino (1894a) did not illustrate this species. According to Ameghino's catalogue and Mones (1986), the mandibular fragment MACN-A 9852 is the type material of the species. However, MACN-A 9852 does not match the original description, because its $\mathrm{m} 3$ exhibits a labial groove in the talonid as in other species of Icochilus. Among the remaining specimens assigned to this species within the Ameghino Collection, other two fragmented mandibles, MACN-A 9853 and MACN-A 9854, neither present the diagnostic characteristics described for the m3. In addition, no material labelled as Icochilus sp., Interatherium sp., Icochilini, Icochilinae and Interatheriidae indet. matches the original description provided by Ameghino (1894a). As a result, the type specimen of Ic. curtus has not been located.

\section{Icochilus hegetotheroides Ameghino, 1894a}

Holotype. MACN-A 9855 (Figs. 6 D-E), anterior cranial fragment, and MACN-A 9856 (Figs. 6 F-G), an incomplete mandible, both of the same individual.

Age and provenance of the type material. Santacrucian SALMA, early Miocene, Santa Cruz Province (Argentina).

Original description (Ameghino 1894a: 17). "Cette espèce se distingue par le grand développement de la paire d'incisives internes supérieures $\left(i{ }^{1}{ }^{1}\right)$, comparables sous ce rapport à celles du genre Hegetotherium. Ces 
incisives sont convexes en avant, concaves en arrière, et avec la surface de la couronne en arc de cercle. La deuxième incisive est petite, et la troisième incisive ainsi que la canine sont atrophiées. La partie antérieure du crâne est très raccourcie et proportionnellement très large. La couronne de chacune des incisives internes a $5 \mathrm{~mm}$. 5 de diamètre transverse en ligne droite. Le palais au niveau des canines a $13 \mathrm{~mm}$. de largeur, et la distance du bord antérieur de la p. ${ }^{l}$ au coin interne de l'i. ${ }^{l}$ est de seulement $46 \mathrm{~mm}$ ".

English translation. This species is distinguished by the great development of the internal upper incisors (I1), similar in this aspect to those of the genus Hegetotherium. These incisors are labially convex, lingually concave, and with an arched surface of the crown. The second incisor is small, and the third incisor and the canine are atrophied. The anterior part of the skull is very short and proportionally very broad. The crown of each internal incisor measures $5 \mathrm{~mm}$. 5 of transverse diameter in a straight line. The palate is $13 \mathrm{~mm}$ wide at the level of the canines, and the distance from the anterior part of P1 to the internal part of I1 is only $46 \mathrm{~mm}$.

Comments. Ameghino (1894a) did not illustrate any specimen of this species. According to Ameghino's catalogue and Mones (1986), MACN-A 9855 (anterior portion of a skull) and MACN-A 9856 (incomplete mandible), which belong to the same individual, are the type specimens of the species. The measurements of MACN-A 9855 (MDL of I1 $=5.5-5.7 \mathrm{~mm}$; width of the palate at the C level $=13.2 \mathrm{~mm}$; length of $\mathrm{I} 1-\mathrm{dP} 1=16.3$ $\mathrm{mm}$ ) match approximately those provided by Ameghino (1894a). Therefore, MACN-A 9855 and MACN-A 9856 are confirmed as the holotype of Ic. hegetotheroides.

\section{Icochilus ulter Ameghino, 1899}

Holotype. MACN-A 11601 (Figs. $6 \mathrm{H}-\mathrm{I}$ ), right mandibular fragment with $\mathrm{p} 3-\mathrm{m} 3$ and left mandibular fragment with $\mathrm{p} 4-\mathrm{m} 1$ series.

Age and provenance of the type material. Astrapothericulan beds (presumably the Pinturas Formation), early Miocene, Santa Cruz Province (Argentina).

Original description (Ameghino 1899: 5). "De la talla del Icochilus extensus, pero de rama mandibular más alta (20 milímetros debajo de la quinta muela)".

English translation. With the size of Icochilus extensus, but with a highest mandibular ramus (20 millimetres below the fifth molar).

Comments. Ameghino (1899) briefly described this species without illustrating it, but he did not mention it in his catalogue. There is no specimen indicated as type of Ic. ulter in the Ameghino Collection. Despite this, Mones (1986) indicated, but with doubts, "MACN-A 10601?" as type specimen; however, this specimen is also indicated by the author as the type of the isotemnid Eochalicotherium crassidens. MACN-A 10601 is in fact a lot constituted by three mandibular fragments - with one tooth each - that belong to the latter species; consequently, it is discarded as the holotype of Ic. ulter. On the other hand, the lot MACN-A 11601, which is composed of two mandibular fragments of the same individual, with right $\mathrm{p} 3-\mathrm{m} 3$ and left $\mathrm{p} 4-\mathrm{m} 1$, is the only material assigned by $\mathrm{F}$. Ameghino to Ic. ulter within the Ameghino Collection. The right fragment matches the only measurement (length of the mandibular ramus below $\mathrm{m} 1=20 \mathrm{~mm}$ ) given by Ameghino (1899). It is worth mentioning that there are two pieces of paper inside the container with Ameghino's handwriting: one that reproduces the original description of the species and another with the name "Icochilus ulter". In the latter, it is also written "10601" but with someone else's handwriting (probably from M. Soria; A. Kramarz, pers. comm.), and the first ' 0 ' was crossed out and replaced by ' 1 '; it is very likely that this mistake led Mones to mention "MACN-A 10601?" as the type of the species. As a result, MACN-A 11601 is identified as the holotype of Ic. ulter.

\section{Conclusions}

Within the Vertebrate Palaeontology Collection at the MLP and the Ameghino National Collection at the MACN, we have identified the type materials of 18 out of the 21 species of the genera Interatherium and Icochilus, four of the former and fourteen of the latter. The main conclusions of this contribution are summarised in Table 1.

For three species of Interatherium and twelve of Icochilus, the status of the type specimen is confirmed, meaning that the material assigned as such in the institutional catalogues - and in some cases already confirmed by 
Mones (1986) (see Tab. 1) - is in fact the specimen used by Ameghino to define the species. For the remaining six species, two dissimilar situations are identified. On the one hand, Interatherium dentatum and Icochilus ulter do not have any type material assigned in Ameghino's catalogue. On the other hand, the type material catalogued by Ameghino for Interatherium rodens, I. supernum, I. brevifrons, Icochilus rotundatus and Ic. curtus are incorrectly assigned, because the specimens do not match the respective original descriptions (Table 1). In the case of Interatherium dentatum, Icochilus rotundatus and Ic. ulter, their types could be identified among the whole sample assigned to each species. In addition, it was possible to complete the type series of Icochilus excavatus and Ic. trilineatus.

TABLE 1. Type specimens of each species of Interatherium and Icochilus according to our results, compared with the status of the materials following Ameghino's catalogue, the catalogue of the Old Collections of the MLP and Mones (1986).

\begin{tabular}{|c|c|c|c|c|}
\hline \multirow[t]{2}{*}{ Species } & \multirow[t]{2}{*}{ Specimen } & \multicolumn{3}{|c|}{ Status according to: } \\
\hline & & $\begin{array}{l}\text { Collections } \\
\text { Catalogues }\end{array}$ & Mones (1986) & This paper \\
\hline \multirow[t]{2}{*}{ Interatherium rodens } & MACN-A 377-387 & Type & ----- & Rejected \\
\hline & MLP 12-2826 & Type & Type & Holotype \\
\hline \multirow[t]{9}{*}{ Interatherium supernum } & MACN-A 357 & $2^{\text {nd }}$ Type & ----- & Rejected \\
\hline & MACN-A 358 & $2^{\text {nd }}$ Type & ----- & Rejected \\
\hline & MACN-A 359 & $2^{\text {nd }}$ Type & ----- & Rejected \\
\hline & MACN-A 424 & $1^{\text {st }}$ Type & ----- & Rejected \\
\hline & MACN-A 540 & ----- & ----- & Rejected \\
\hline & MLP 12-1846 & Paratype & Type & Rejected \\
\hline & MLP $12-1878$ to $12-1879$ & Paratype & Type & Rejected \\
\hline & MLP $12-1885$ to $12-1887$ & Paratype & Type & Rejected \\
\hline & MLP 12-1921 & Paratype & Type & Rejected \\
\hline \multirow[t]{2}{*}{ Interatherium brevifrons } & MACN-A 3440 & Type & ----- & Rejected \\
\hline & MACN-A 3441 & ------ & Type & Rejected \\
\hline Interatherium anguliferum & MACN-A 3444 & Type & Type & Holotype \\
\hline Interatherium interruptum & MACN-A 3445 & Type & Type & Holotype \\
\hline Interatherium dentatum & MACN-A 9863 & ----- & ------ & Holotype \\
\hline \multirow[t]{3}{*}{ Icochilus extensus } & MACN-A 1083 & Type & Type & Lectotype \\
\hline & MACN-A 1084 & Type & Type & Lectotype \\
\hline & Four isolated teeth & ------ & ------ & Paralectotypes (not found) \\
\hline \multirow[t]{6}{*}{ Icochilus excavatus } & MACN-A 177 & Type & Type & Syntype \\
\hline & MACN-A 178 & Type & Type & Syntype \\
\hline & MACN-A 179 & Type & Type & Syntype \\
\hline & MACN-A 180 & Type & Type & Syntype (not found) \\
\hline & MACN-A 9681 & ------ & ------ & Syntype \\
\hline & Isolated m3 & ------ & ------ & Syntype (not found) \\
\hline Icochilus undulatus & MACN-A 373 & Type & Type & Holotype \\
\hline \multirow[t]{3}{*}{ Icochilus rotundatus } & MACN-A 3588 & Type & Type & Rejected \\
\hline & MACN-A 371 & ------ & ------ & Syntype \\
\hline & MACN-A 372 & ----- & ------ & Syntype \\
\hline Icochilus robustus & MACN-A 3454 to 3505 & Type & Type & Holotype \\
\hline Icochilus senilis & MACN-A 3596 to 3630 & Type & Type & Holotype \\
\hline
\end{tabular}


TABLE 1. (Continued)

\begin{tabular}{lllll}
\hline Species & Specimen & \multicolumn{2}{l}{ Status according to: } & \\
\cline { 2 - 4 } & & $\begin{array}{l}\text { Collections } \\
\text { Catalogues }\end{array}$ & Mones (1986) & This paper \\
\hline Icochilus lamellosus & MACN-A 3631 & Type & Type & Holotype \\
Icochilus trilineatus & MACN-A 3633 & Type & Type & Syntype \\
& MACN-A 3651 to & ----- & ----- & Syntype \\
Icochilus anomalus & MACN-A 3657 & & & Holotype only if it corresponds to \\
& MACN-A 3634 & Type & Type & photograph No. 309 of Scott's catalogue \\
Icochilus truncus & & & & (specimen not found) \\
Icochilus crassiramis & MACN-A 3635 & Type & Type & Holotype \\
Icochilus multidentatus & MACN-A 3637 & Type & Type & Holotype \\
& MACN-A 3638 & Type & Type & Lectotype \\
Icochilus curtus & MACN-A 9852 & Type & Type & Paralectotype \\
Icochilus hegetotheroides & MACN-A 9855 & Type & Type & Holotype \\
& MACN-A 9856 & Type & Type & Holotype \\
Icochilus ulter & MACN-A 11601 & ----- & ----- & Holotype \\
& MACN-A 10601 & ----- & Type & Rejected \\
\hline
\end{tabular}

On the contrary, the type materials of Interatherium supernum, I. brevifrons, Icochilus curtus and Ic. anomalus were not found in the studied collections - by direct observations (e.g., MACN and MLP) and/or by means of photographs (e.g., AMNH, FMNH, YPM and ZMK) - In the case of Ic. anomalus, there is a photograph of its holotype in Scott's photographic catalogue (Vizcaíno et al. 2017), which allows inferring that it got lost —or even sold-after 1901. In the case of I. supernum, it is worth mentioning that all catalogued type specimens of Interatheriinae collected by Carlos Ameghino in 1887 in Santa Cruz Formation and later illustrated by Florentino in the Atlas (Ameghino 1889) are housed at the MACN-A, meaning that they were deviated by Ameghino from the MLP - their original reservoir - to his private collection before leaving the institution in 1888. This fact leads to assume that, as the type of I. supernum was not illustrated, it would remain stored in the MLP without being part of Ameghino's collection at MACN. Nevertheless, it has neither been located in the MLP collection—or in any other studied collection-.

As the designation of the type species of Icochilus was recognised to be pending, Icochilus extensus is herein designated as such because its lectotype, also designated in this contribution, was used by Ameghino (1889) to characterise the genus. Finally, we also selected the lectotype (and paralectotype) of Ic. multidentatus, because only one of the two syntypes undoubtedly exhibits the diagnostic characteristic of the species.

The identification of the type specimens is a fundamental key for advancing in the systematic revision and getting a confident view of the Interatheriinae diversity.

\section{Acknowledgements}

We thank the editorial staff and the reviewers (A. Kramarz and M. Reguero) for their useful comments on this manuscript. We are grateful to the curators A. Kramarz (MACN) and M. Reguero (MLP) for making available the collections under their care, and Tec. S. M. Álvarez for her help and goodwill during her time working at the MACN. We also thank S. Vizcaíno (MLP) for providing the photographs of the Scott's catalogue. This is a contribution to projects ANPCyT 2013-0389, UNLP 11/N750, NSF EAR0851272 and EAR1348259. Finally, this work was partially supported by Universidad Nacional de Luján, grants CCD-CD: 054/12, CBLUJ 0000030-18 and CONICET-PIP 781 to J.C. Fernicola. 


\section{References}

Ameghino, F. (1887a) Observaciones generales sobre el orden de mamíferos extinguidos sub-americanos llamados Toxodontes (Toxodontia) y sinopsis de los géneros y especies hasta ahora conocidos. Anales del Museo de La Plata, 1 (1), 1-66.

Ameghino, F. (1887b) Enumeración sistemática de las especies de mamíferos fósiles coleccionados por Carlos Ameghino en los terrenos eocenos de la Patagonia austral y depositados en el Museo La Plata. Boletín del Museo de La Plata, 1, 1-26.

Ameghino, F. (1889) Contribución al conocimiento de los mamíferos fósiles de la República Argentina. Actas de la Academia Nacional de Ciencias de Córdoba, 6, i-xxxii, 1-1027, atlas of 98 pls.

Ameghino, F. (1891) Nuevos restos de mamíferos fósiles descubiertos por Carlos Ameghino en el Eoceno inferior de la Patagonia austral. Especies nuevas, adiciones y correcciones. Revista Argentina de Historia Natural, 1 (5), $289-328$.

Ameghino, F. (1894a) Énumération synoptique des espèces de mammifêres fossiles des formations éocènes de Patagonie. Coni é hijos, Buenos Aires, 196 pp.

Ameghino, F. (1894b) Enumération synoptique des espèces de mammifères fossiles des formations éocènes de Patagonie. Boletín de la Academia Nacional de Ciencias de Córdoba, 13, 259-445.

Ameghino, F. (1899) Sinopsis geológico-paleontológica de la Argentina. Suplemento (Adiciones y correcciones). Imprenta La Libertad, La Plata, pp. 1-13.

Bond, M. (2000) Carlos Ameghino y su obra édita. Publicación Especial de la Asociación Paleontológica Argentina, 12 (1), 33-41.

Bordas, A. (1936) Los Peltateloidea de la colección Ameghino. Peltephiloda. (Infraorden de los Xenarthra). Physis, 12 (41), 118.

Cassini, G.H., Cerdeño, E., Villafañe, A.L. \& Muñoz, N.A. (2012) Paleobiology of Santacrucian native ungulates (Meridiungulata: Astrapotheria, Litopterna, and Notoungulata). In: Vizcaíno, S.F, Kay, R.F. \& Bargo, S. (Eds.), Early Miocene Paleobiology in Patagonia, High Latitude Paleocommunities of the Santa Cruz Formation. Cambridge University press, New York, pp. 243-286. https://doi.org/10.1017/cbo9780511667381.015

Ciancio, M.R. \& Carlini, A.A. (2008) Identificación de ejemplares tipo de Dasypodidae (Mammalia, Xenarthra) del Paleógeno de Argentina. Revista del Museo Argentino de Ciencias Naturales, 10 (2), 221-237. https://doi.org/10.22179/REVMACN.10.279

Cione, A.L., Azpelicueta, M.M., Bond, M., Carlini, A.A., Casciotta, J.R., Cozzuol, M.A., de la Fuente, M., Gasparini, Z., Goin, F.J., Noriega, J., Scillato-Yané, G.J., Soibelzon, L., Tonni, E.P., Verzi, D. \& Vucetich, M.G. (2000) Miocene vertebrates from Entre Ríos province, eastern Argentina. In: Aceñolaza, F.G. \& Herbst, R. (Eds.), El Neógeno de Argentina. INSUGEO, Tucumán, 14, 191-237.

Croft, D.A. \& Anderson, L.C. (2008) Locomotion in the extinct notoungulate Protypotherium. Paleontología Electrónica, 11 (1), 1-20.

Cruz, L.E., Fernicola, J.C. \& Porpino, K.D.O. (2013) A propósito del neotipo de Panochthus tuberculatus (Owen, 1845) (Mammalia, Xenarthra, Glyptodontia). Revista Brasileira de Paleontologia, 16 (2), 331-340. https://doi.org/10.4072/rbp.2013.2.13

De Iuliis, G., Fernicola, J.C. \& Racco, A. (2016) On the Publication and Pagination of Ameghino's (1894) Taxonomy of Santacrucian Mammals. Ameghiniana, 53 (4), 517-522. https://doi.org/10.5710/amgh.26.01.2016.2909

Elissamburu, A. (2012) Estimación de la masa corporal en géneros del Orden Notoungulata. Estudios Geológicos, 68 (1), $91-$ 111. https://doi.org/10.3989/egeol.40336.133

Fernández, M., Fernicola, J.C., Cerdeño, E. \& Reguero, M.A. (2018) Identification of type materials of the species of Protypotherium Ameghino, 1885 and Patriarchus Ameghino, 1889 (Notoungulata: Interatheriidae) erected by Florentino Ameghino. Zootaxa, 4387 (3), 473-498. https://doi.org/10.11646/zootaxa.4387.3.4

Fernicola, J.C. (2011a) Implicancias del conflicto Ameghino-Moreno sobre la colección de mamíferos fósiles realizada por Carlos Ameghino en su primera exploración al río Santa Cruz, Argentina. Revista del Museo Argentino de Ciencias Naturales, 13 (1), 41-57.

Fernicola, J.C. (2011b) Ascenso, auge y caída de la sociedad entre Florentino Ameghino y Francisco P. Moreno. Publicación Especial de la Asociación Paleontológica Argentina, 12 (1), 35-49.

Hitz, R., Reguero, M.A., Wyss, A.R. \& Flynn, J.J. (2000) New interatheriines (Interatheriidae, Notoungulata) from the Paleogene of central Chile and southern Argentina. Feldiana, Geology, 42, 1-26.

Hooker, J.J. (1986) Mammals from the Bartonian (middle/late Eocene) of the Hampshire Basin, southern England. Bulletin of the British Museum (Natural History) Geology series, 39 (4), 191-478.

ICZN (2000) Código internacional de nomenclatura zoológica. 4th edition, CSIC-MNCN Madrid, Caja España, The International Comission on Zoological Nomenclature and Sociedad de Amigos del MNCN (eds), Madrid, 156 pp.

Marshall, L.G. (1980) Systematics of the South American marsupial family Caenolestidae. Fieldiana Geology, 5, 1-145. https://doi.org/10.5962/bhl.title.3314

Mones A. (1986) Palaeovertebrata Sudamericana. Catálogo Sistemático de los Vertebrados Fósiles de América del Sur, Parte I. 
Preliminary List and Bibliography. Courier Forschungsinstitut Senckenberg, 82, 1-625.

Moreno, F.P. (1882) Patagonia, resto de un antiguo continente hoy sumergido. Contribuciones al estudio de las colecciones del Museo Antropológico y Arqueológico de Buenos Aires. Anales de la Sociedad Cientifica Argentina, 14, 97-131.

Reguero, M.A., Ubilla, M. \& Perea, D. (2003) A new species of Eopachyrucos (Mammalia, Notoungulata, Interatheriidae) from the late Oligocene of Uruguay. Journal of Vertebrate Paleontology, 23 (2), 445-457. https://doi.org/10.1671/0272-4634(2003)023[0445:ansoem]2.0.co;2

Roth, S. (1903) Los ungulados sudamericanos. Anales del Museo de La Plata, 5, 1-36.

Simpson, G.G. (1984) Discoverers of the lost World: An Account of Some of Those who Brought Back to Life South American Mammals Long Buried in the Abyss of Time. Yale University Press, New Haven \& London, 222 pp.

Smith, J.B. \& Dodson, P. (2003) A proposal for a standard terminology of anatomical notation and orientation in fossil vertebrate dentitions. Journal of Vertebrate paleontology, 23 (1), 1-12. https://doi.org/10.1671/0272-4634(2003)23[1:apfast]2.0.co;2

Townsend, K.E. \& Croft, D.A. (2008) Diets of notoungulates from the Santa Cruz Formation, Argentina: new evidence from enamel microwear. Journal of Vertebrate Paleontology, 28 (1), 217-230. https://doi.org/10.1671/0272-4634(2008)28[217:donfts]2.0.co;2

Vera, B. \& Cerdeño, E. (2014) Systematic revision of Antepithecus brachystephanus Ameghino, 1901, and dental eruption sequence in Eocene "notopithecines" (Notoungulata) from Patagonia. Geobios, 47 (3), 165-181. https://doi.org/10.1016/j.geobios.2014.02.001

Vizcaíno, S.F. (2011) Cartas para Florentino desde Patagonia. Crónica de la correspondencia édita entre los hermanos Ameghino (1882-1902). Publicación Electrónica de la Asociación Paleontológica Argentina, 12 (1), 51-67.

Vizcaíno, S.F., Bargo, M.S. \& Fernicola, J.C. (2013) Expediciones paleontológicas durante los Siglos XIX y XX a la Formación Santa Cruz (Mioceno Inferior, Patagonia) y destino de los fósiles. Actas del $3^{\text {er }}$ Congreso Argentino de Historia de la Geología, Salta, 15 pp.

Vizcaíno, S.F., de Iuliis, G., Brinkman, P.D., Kay, R.F. \& Brinkman, D.L. (2017) On an album of photographs recording fossils in the "Old Collections" of the Museo de la Plata and Ameghino's private Collection at the beginning of the XXth century”. Publicación Electrónica de la Asociación Paleontológica Argentina, 17, 14-24. https://doi.org/10.5710/PEAPA.21.06.2017.244

Zittel, K.A. (1893) Handbuch der Palaeontologie. Vol 4. Vertebrata (Mammalia). Oldenbourg, München, 293 pp. 